\title{
Reading the Constitution as Spoken
}

\author{
Jed Rubenfeld ${ }^{\dagger}$
}

\section{CONTENTS}

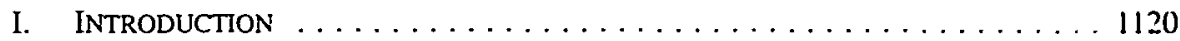

II. The Model of Speech: Conversation and Its Discontents . . . . . . 1123

A. The Freedom of Speech . . . . . . . . . . . . . . . . . 1123

B. Constitutional Interpretation on the Model of Speech $\ldots \ldots \ldots \ldots 1127$

1. The Voice of the Past .................... . 1127

2. The Voice of the Present .................... 1131

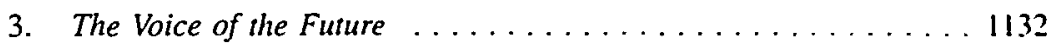

C. The Impasse of Time in the Model of Speech ........... 113.4

D. Where Writing Was, Voice Will Be ............... 1140

E. Conclusion ......................... . . 1142

III. Self-Government over Time: The Model of Writing $\ldots \ldots \ldots \ldots 1143$

A. The Freedom To Write . . . . . . . . . . . . . . . . 1144

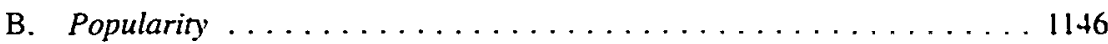

C. Commitmentarianism ................... 1154

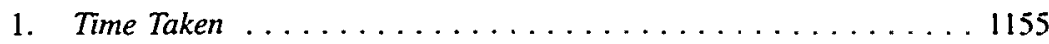

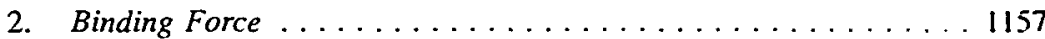

3. The Unknown ...................... 1160

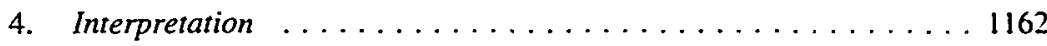

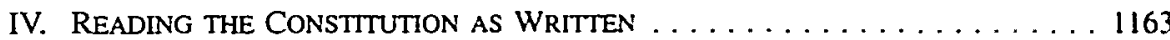

A. Judicial Review: Unwritten Law . . . . . . . . . . . . 1164

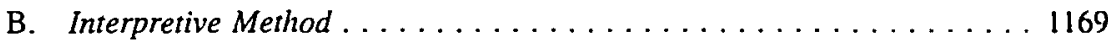

1. Paradigm Cases ......................... . 1169

2. Intent-To-Prohibit, Intent-To-Permit $\ldots \ldots \ldots \ldots \ldots \ldots \ldots 1171$

3. Powers .......................... 1173

4. Precedent ............................. 1177

C. Application: The Just Compensation Clause . . . . . . . . . 1179

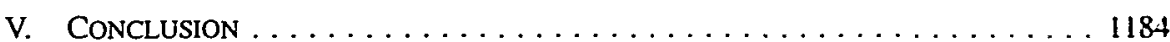

$\dagger$ Professor, Yale Law School. Special thanks to Amy Chua. Bruce Ackerman. Akhul Amar, Guido Calabresi, Stephen Carter, Jules Coleman, Owen Fiss, and Paul Kahn.

1119 


\section{INTRODUCTION}

Constitutional law, which speaks today to almost everything, has nothing to say on one subject. It has no account of its own interpretive method.

The truth is that most of us don't know if the Supreme Court is "interpreting" the Constitution at all anymore. Or whether it ever did. Or what exactly it would mean for the Court to do so. We have in this country a very successful practice of constitutional interpretation coupled with a thoroughgoing cynicism about its coherence and legitimacy.

Perhaps this cynicism exists because what passes for constitutional interpretation really is "unprincipled" and "illegitimate." But perhaps there are deeper problems in the way we think about constitutional law today than in the way we practice it. Could it be that what passes for constitutional theory is somehow unable to comprehend constitutional law?

This possibility raises two fundamental questions.

First, is there an interpretive account of actual constitutional practice that would make sense of it-that would capture in general fashion what our courts are doing and have done with the Constitution? To ask for an interpretive account is to ask whether, despite the obvious introduction of normative judgments into the law, and despite all the departures from original intent, the courts' doings can yet be understood as interpretation-as the elaboration of an interpretive method, rather than as a hodgepodge of policy decisions or as a re-writing of the text.

Second, if so, is that interpretive method legitimate? This is to ask whether there is an account of the proper judicial role in a democracy from which the method plausibly follows. If there is such an account, we need to explain why it eludes contemporary constitutional thought.

There is an interpretive method underwriting constitutional practice, and it is consistent with the proper judicial role in a democratic polity. It has eluded our grasp because the prevailing schools of constitutional interpretation, various as they are, are linked by a common understanding of democracy-an understanding that in fact misunderstands what the judiciary is and ought to be doing when it interprets the Constitution. Or so at least I shall argue.

In what follows, I distinguish a very familiar understanding of democracy, which I will call speech-modeled, from a less familiar one, which I associate with written constitutionalism. The speech-modeled conception imagines democracy in terms of a conformity between governance and the democratically authoritative will of some particular time. Ideally, democratic legitimacy would be attained on this view if the voice of state authority were none other than the voice of the people itself.

1. ROBert H. BORK, THE TEMPTING OF AMERICA 73, 74 (1990). 
Within this conception, there are three basic ways to understand constitutional law, if such law is not to appear fundamentally illegitimate. First, constitutional law might be thought obliged to adhere to what the Framers or ratifiers meant to say or would have said on any given question. because this was the understanding democratically ratified. Second, the function of constitutional law might be understood solely or primarily as a matter of safeguarding the process that allows today's voters to make their voices heard. Third, judges might be thought obliged to speak for the people's evolving constitutional ideals. These speech-modeled positions are staples of contemporary constitutional commentary. They stake out, respectively, the basic claims made by originalists, ${ }^{2}$ process-based theorists, ${ }^{3}$ and those who advocate fundamental-values approaches to constitutional law."

Each of these three positions is logically available within the model of speech, but each is also subject to fatal counterthrusts from the others. Originalism cannot explain the supremacy of the democratic voice of the past over that of the present; processualism cannot explain the manifestly substantive commitments embodied in numerous constitutional provisions; and fundamentalism (for lack of a better word) cannot explain the judiciary's competence to speak for the people. But these thrusts and parries are the best the model of speech can do. Its only alternative-and it is always a live alternative-is to regard constitutionalism as radically antidemocratic.'

The model of speech cannot do justice to constitutional self-government. Written constitutionalism demands its own conception of selfgovernment-self-government on the model of writing.

Self-government on the model of writing understands itself as a generation-spanning endeavor. It rejects the idea that constitutional constraints are at best democratic efforts by a majority at one moment to impose antidemocratic limitations on majorities tomorrow, or at best procedural efforts to create democratic institutions, or devices through which judges are positioned to speak for a contemporary consensus. It begins instead with the premise that living up to enduring, substantive constitutional commitments is integral to self-government itself.

2. See, e.g., RAOUL BERGER, GOVERNMENT BY JUDICIARY 363-72 (1977). BORK, supro note 1. al 143-60; RICHARD A. POSNER. THE FEDERAL COURTS 261-93 (1985): Eduin Mcese. Interpreting the Constitution, in INTERPRETING THE CONSTITUTION 13, 15 (Jack N. Rakove ed., 1990)

3. See, e.g., JOHN HART ELY, DEMOCRACY AND DISTRL'ST (1980).

4. Influential work in this area includes ALEXANDER M. BICKEL. THE LEAST DAvGerol S BRAYCH (1962); Ronald Dworkin, a Matter of Principle (1985). Laurexce h Tribe. americal ConstITUTIONAL LAW §§ 15-1 to -2l (2d ed. 1988); Thomas C Grey. Do Wic Have an Unuritten Constitution?, 27 STAN. L. REV. 703 (1975).

5. See, e.g., PAUL W. KAHN, Legitimacy AND History 8 (1992) ("The constututional state cannot support a claim of legitimate self-government ...."); Lino A. Graglia. How the Constiturun Distappeared. in INTERPRETING THE CONSTITUTION. supra note 2, at 35. 37 ("Constututional limitations on popular government are undoubtedly undemocratic ...."). 
True self-government would not be achieved in a glorious moment at which law was made by a univocal, deliberate declaration of the voice of the people. To conceive of self-government on the model of writing is to think through the possibility that self-government is attainable not at any one time, but only over time.

What does this imply for constitutional interpretation? Reading the Constitution as written opens up the possibility of an interpretive method neither originalist, literalist, processualist, nor fundamentalist. I call it commitmentarian.

In interpreting a textually specified right, suppose that what those who fought for this right fought most centrally to prohibit received paramount deference, while what they understood their prohibition to permit received little or none at all. From the paradigm cases of what the right was enacted to abolish, courts would formulate rules or principles of application mediating between the general language of the text and particular fact patterns; these rules or principles and their requirements would emerge through case-by-case elaboration; and in applying them, courts could with full authority strike down laws that the Framers (however that term is defined) never intended to be covered. A parallel methodology would apply to the grants of power, only reversed: Here, what was centrally meant to be permitted would form the paradigm cases of applicability, whereas what was understood to be out of reach of the grant of power would receive little or no deference at all.

Put aside for the moment the obvious questions-how are paradigm cases to be identified? how can intent-to-prohibit and intent-to-permit be distinguished? what could justify privileging one over the other?-and suppose that this methodology underwrote our interpretive regime. We could then expect constitutional law to bear the following attributes. It would be neither originalist nor deferential to current majority will; there would be a strong pressure within the interpretive process to expand both constitutional rights and powers; adjudication would proceed in common-law-like fashion; finally, the normative component of this practice would render constitutional law radically open to different ideological orientations, yet its practitioners would nonetheless feel its methodological restraints. Obviously, I mean this list to strike readers as familiar.

Part II of this Article describes the model of speech, traces its operation in various accounts of constitutional interpretation, and argues its inability to do justice to constitutional law. Part III elaborates the alternative model of writing. Part IV discusses the implications of the model of writing for constitutional law: its theory of judicial review, its position on "unwritten" rights, and its method for reading the constitutional text. 


\section{THE MOdel OF SPEech: CONVERSATION AND ITS Discontents}

To avoid confusion: I am not going to argue that the Constitution demands a form of interpretation peculiar to the written word, as if there were one hermeneutic applicable to all written records and another to all oral utterances. No categorical distinction between writing and speech exists for interpretive purposes. Plato's dialogues would not demand one interpretation when read. but another when spoken, if it were even possible to distinguish sharply writing from speech in such a text. ${ }^{6}$

But if writtenness and spokenness as such do not demand different forms of interpretation, what can it mean to speak of "speech-modeled" interpretation at all?

Interpretation is speech-modeled if it seeks to resolve textual ambiguities by reference to, or to replace a text altogether with, acts of speech or voice. For example, when in ordinary conversation I ask you to clarify something you have said, I am engaging in the simplest form of speech-modeled interpretation. I am trying to resolve an ambiguity in your previous statement by soliciting further acts of speech. But speech-modeled interpretation does not require that these further speech acts be found in actual spoken utterances; they may also be found in hypothetical utterances or even in a written record.

How can a 200-year-old text like the Constitution be interpreted on the model of speech? In a variety of ways, as we shall see shortly. But first let's explore the premises that underlie every speech-modeled approach to constitutional law. These premises do not sound in a general theory of language or meaning. Speech-modeled constitutional interpretation rests not on linguistic theory, but on political theory. Not every advocate of speechmodeled constitutional interpretation is a political theorist, but every version of speech-modeled constitutional interpretation emerges from a certain conception of democratic self-government, in which speech plays a definitive role.

Let's begin by identifying this speech-modeled conception of selfgovernment.

\section{A. The Freedom of Speech}

For centuries, an insistent rhetoric of speech-or voice, talk, saying, conversation, dialogue, and other speech cognates-has made itself heard in

6. Nor will I argue that the profound societal changes implied by the passige from oral to written cuitures, see, e.g., JACK GOODY, THE LOGIC OF WRITING AND THE ORGANiZATION OF SOCIETY (1986). Walter J. ONG, ORALITY and Literacy: THE TEChNologizing OF THE WORD (1982), demand by themselves a transformation in the way a society interprets its canonical texts. 
political thought, particularly when that thought has expounded the democratic ideal. $^{7}$

This "speechifying" shows little ideological self-restraint; it attracts republican, liberal, and even fascist theorists of popular rule. "[A]ny tongue," wrote Rousseau, "with which one cannot make oneself understood to the people assembled is a slavish tongue. It is impossible for a people to remain free and speak [such a] tongue." knew and acknowledged that talking and discussion are their proper business," they would not "attempt to do what they cannot do well-to govern and legislate." And for Carl Schmitt: "The natural way in which a People expresses its immediate will is through a shout of Yes or No by an assembled multitude, the Acclamation."10

Examples, particularly from this century, abound. Hans Kelsen: "The will of the community, in a democracy, is always created through a running discussion between majority and minority ...." Jürgen Habermas: A democratic politics must strive toward implementation of "a common will, communicatively shaped and discursively clarified in the political public sphere." 2 Claude Lefort: "[M]odern democracy invites us to replace the notion ... of a legitimate power, by the notion of a regime founded upon the legitimacy of a debate as to what is legitimate and what is illegitimate . . ."13 Stephen Holmes: "Democracy is government by public discussion ...."14

7. Jacques Derrida seems to be the first to have given sustained attention to this speech-centered rhetoric in political thought. See, e.g., JACQUES DERRIDA, OF GRAMMATOLOGY (Gayatri C. Spivak trans., 1976). My "model of speech" borrows heavily from Derrida's analysis in many respects, but departs from it altogether in others. This is not the place, however, for a detailed comparison.

8. Jean-Jacques Rousseau, Essay on the Origin of Languages Which Treats of Melody and Musical Imitation, in ON THE ORIGIN OF LANGUAGE 73 (John H. Moran trans., 1966). For a discussion of this passage, see DERRIDA, supra note 7, at 138, 168.

9. J.S. MILL, CONSIDERATIONS ON REPRESENTATIVE GOVERNMENT (1861), reprinted in ON LIBERTY AND Considerations ON REPRESENTATIVE GOVERNMENT 173 (R.B. McCallum ed., 1946). Mill's description of representative bodies is instructive: "[T]hey are not a selection of the greatest political minds in the country," but rather, when "properly constituted, a fair sample of every grade of intellect among the people which is at all entitled to a voice in public affairs." Id. at 173, 174. The members of Mill's "popular assembly" resemble the respondents in a "properly constituted" public opinion survey or focus group: Their legitimate role in government derives from their capacity to speak representatively. Thus did it follow that the proper role of the assembly was to talk, not to govern or legislate.

10. CARL SCHMITT, Verfassungslehre 83 (1928) ("Die natürliche Form der unmiltelbaren Willensäußerung eines Volkes ist der zustimmende oder ablehnende Zuruf der versammelten Menge, die Akklamation.").

11. Hans Kelsen, General Theory of Law and State 287 (Anders Wedberg trans., 1961).

12. JÜREN HABERMAS, THE THEORY OF COMMUNICATIVE ACTION 81 (Thomas McCarthy trans., 1987).

13. Claude Lefort, Democracy and Political Theory 39 (David Macey trans., 1988).

14. Stephen Holmes, Precommitment and the Paradox of Democracy, in CONSTITUTIONALISM AND DEMOCRACY 195, 233 (Jon Elster \& Rune Slagstad eds., 1988); see also Bruce Ackerman, Constitutional Politics/Constitutional Law, 99 YALE L.J. 453, 477 (1989) ("[T]he Constitution is best understood as . . . an evolving language of politics through which Americans have learned to talk to one another in the course of their centuries-long struggle over their national identity."). 
A certain constellation of concepts is usually prominent throughout this thinking: the desideratum of popular will or consensus, an assembly of the people (or popular representatives) to form or at least to give voice to this consensus, and the enactment of law thus consented to. ${ }^{15}$ These concepts are not new: On the contrary, at bottom they measure modern democracy through the nostalgic ideal of the Greek polis. ${ }^{16}$ Adherents of this view understand self-government (pared down to its essentials) ideally to consist of governance conforming to a mental state (usually called will) ascribed to the governed (usually through an act of consent) at a specified time (for example, the moment at which a vote is taken in a popular assembly). These are the definitive elements of self-government conceived on the model of speech. There should be nothing unfamiliar in this conception. A self is self-governing, on this view, if governed by its own will, not by another's; democracy demands, as a result, that government have the consent of the governed.

But why speech? Why does this demand for government by popular will and consent give rise in turn to a demand to pay heed to vocal utterances? Why is it so natural, once self-government has been identified as governance by the self's will, to say that self-government ideally exists when "the voice of authority is nothing other than the voice of the self?"17

Because of the seeming immediacy with which voice expresses will: because of the seeming unity to be achieved, at any given moment, between utterance and mental state. Due to this putative immediacy, speech or voice is called to the scene whenever the authoritative will is to be produced and expressed at first hand. Writing outlasts the moment of will that was its source, raising the danger that the text will have to be interpreted without clarification by the authoritative speaker. If the will of some self at some particular time is to govern, interpretation of that will is a very second-best solution. The authoritative will should speak for itself-in its own, immediate voice. When instead there is a writing, particularly a spare and general writing, and some new set of individuals comes to be charged with interpreting it, the immediacy of voice and hence self-government itself will be in jeopardy. "Interpretation" will come to seem dangerously like rule by interpreters.

15. See, e.g., Mill, supra note 9. at 170-74: Jean Jacoles Rousseau. THe Social Contract (1762) [hereinafter RousSEAU, SOCIAL CONTRACT], reprinted in THE SOCIAL CONTRACT ANo Discolrses 89-92 (G.D.H. Cole trans.. 1950) [hereinafter SOCIaL CONTRACT AND DiscoutrSES]. SCIMITt. supra note 10, at 83. In new forms, the same constellation is evdent in JOHN RAWLS. A THEORY OF J(STICE (1971), and all those who understand democracy through a public-dialogic idea. Sec. C.g. BRtCE ACKERMA., WE THE PEOPLE: Foundations (1991): HaBermas. supra note 12

16. See, e.g., Bruce A. Ackerman. The Storrs Lectures: Discovernng the Consturuon. 93 YALE LJ 1013. 1043 (1984). There are equally nostalgic modern analogues. Sec. e.g. ALEXANDER MEIKLEJOHY.

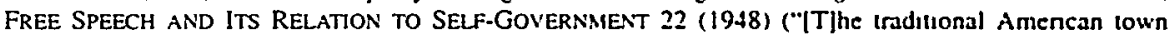
meeting. . . . is commonly, and rightly, regarded as a model by which free poltucal procedures may be measured. It is self-government .... .).

17. KAHN, supra note 5 , at 8 . 
In the end, a particular voice lures this conception of self-government: the voice of the people. Ideally, this voice would be declared at a sublime "constitutional moment," supplying the supreme, immediate, and indeed the only true source of legitimate law. Rousseau affirmed it: "[T] people is in fact the voice of God."

If all a people is called upon to do is to give or withhold its consent to proposed acts of government, the model of speech is in complete command. So conceived, virtually all a people need do to discharge its duties in a democratic politics is to listen and speak-first to arrive at a consensus, and then to pronounce the ultimate yes or no at a particular moment. The rest would be up to governmental officials, whose duty it would be to conform governance to the will of the people thus expressed.

What gives this structure plasticity, however-what makes it attractive to thinkers as far apart as Rousseau and $\mathrm{Mill}^{20}$ - is the capaciousness of the concept of popular will. Most significantly, this will can be conceived not only in collectivist, but also in individualist, terms. The "voice of the people" need not express a "general will" said to belong to some organic body politic. ${ }^{21}$ It may simply express the will of a majority of self-interested individuals.

Liberalism's skepticism about a collective popular "self" never turned it away from the model of speech. On the contrary, the inviolability of individual voice becomes the primary tenet of liberal constitutionalism, a tenet capable of producing simultaneously a demand for individual autonomy and, through the formula "one person one vote," the view that democracy means nothing other than majority rule. ${ }^{22}$ Liberalism has been as firmly speech-modeled as republicanism; it simply demands that government pay heed to many voices, not only to one. Thus, the freedom of speech, although the term has radically different meanings as applied to their respective texts, could be as central to Mill as it was to Rousseau, and the "commanding voice of the People" can be as organizing a concept for Bruce Ackerman ${ }^{23}$ as it was for Carl Schmitt. ${ }^{24}$

18. ACKERMAN, supra note 15 , at 267.

19. Jean Jacques Rousseau, A Discourse on Political Economy, in SoCIAL CONTRACT AND DISCOURSES, supra note 15 , at 291.

20. Despite Rousseau's adamant opposition to representative politics, he was unwilling to confer directly on the people the power to write laws. See ROUSSEAU, SOCIAL CONTRACT, supra note 15, at 39-40. The people assembled was to exercise only the power of consent to laws proposed by someone better suited to the task. See id. at 37-38, 106. And Mill, despite his professed desire to remove the people from the business of legislating, similarly allowed to the popular assembly the ultimate power of consent to proposals by those trained in legislation. See MILL, supra note 9, at 170.

21. ROUSSEAU. SOCIAL CONTRACT, supra note 15 , at 15.

22. See, e.g., Frederick SCHAUER, FREe SPEeCH: A PHILOSOPHICAL ENQUiRy 40 (1982) (“Any distinct restraint on majority power, such as a principle of freedom of speech, is by its nature antidemocratic, anti-majoritarian."); Jon Elster, Introduction to CONSTTTUTIONALISM AND DEMOCRACY, supra note 14, at 1,1 ("Democracy I shall understand as simple majority rule, based on the principle 'One person one vote." ).

23. ACKERMAN, supra note 15 , at 185 .

24. SCHMITT, supra note 10 , at $81-82$. 
But what does the model of speech do when a people writes? To be sure, speech-modeled thought is perfectly prepared to allow day-to-day writings (books, newspapers, and so on) into the democratic "conversation."'s But at the moment of truth-at the moment when the authoritative popular consensus is to be expressed and the state constituted in accordance with popular will-the model of speech cannot comprehend the written.

Faced with a written constitution, the model of speech will invariably view this text, in its writtenness, as a compromise with or imperfect approximation of a spoken declaration of the authoritative will. It will view interpretation of the text as a dangerous supplement, a necessary evil. It will not be able to recognize the radical departure from speech-modeled self-government made possible by written constitutionalism.

Written constitutionalism confronts the model of speech with a quandary. How is self-government to function when the people assembles only at longseparated and irregular intervals, producing not an authoritative voice but written constitutional law, after which governance is delegated to a variety of representative agents? The various speech-modeled responses to this problem create a temporal equivocation within the model of speech from which it can never fully extricate itself.

\section{B. Constitutional Interpretation on the Model of Speech}

Three overarching positions on constitutional law are available within the model of speech, if it is not to reject such law as fundamentally illegitimate. Each answers the problem just posed. Within and sometimes between these three positions, a great many of the most influential contemporary approaches to constitutional interpretation elaborate themselves.

\section{The Voice of the Past}

Originalism demonstrates the first way in which constitutional law can be made legitimate on the model of speech. Originalism demands adherence (as nearly as possible) to the democratically authoritative voice of the past.

The speech modeling in originalism could not be more explicit. In interpreting a constitutional provision, the originalist always asks what the Framers meant to say when enacting the text, or what they did say while debating it, or what they would have said about today's constitutional questions had they been asked. These phrases are not mere figures of speech. The originalist attempts to resolve textual ambiguity by reference to authoritative speech acts, whether found in a "transcription of what was said"

25. See, e.g., KELSEN, supra note 11 , at 287-88. 
at certain debates, ${ }^{26}$ or derived from an imaginary conversation with the Framers to "figure out" how they "would probably have answered your question." "27 In either case, the originalist applies the same interpretive strategy: If the text isn't clear, see if the original lawmakers can somehow be made to tell us, out of their own mouths and in plain speech, what they wanted to say. Don't take my word for it: Originalism deliberately reads "the written word on the model of speech."28

And why must constitutional meaning be determined by what the Framers wanted to say, or said they meant, or would have said?

Originalists like to respond that only originalism bars judges from constitutionalizing their own value judgments, ${ }^{29}$ or that only originalism can establish a stable body of law. ${ }^{30}$ But these defenses are incomplete. Interpreting the Constitution according to what the current President would say about it would (in principle) equally disallow judicial policymaking. Interpreting it according to what King George III would have said about it would (in principle) create an equally fixed body of law. On what ground do originalists select the particular voices, the particular speech acts, on which they rely?

The answer of course is that originalists deem these voices to be authoritative as a matter of democratic legitimacy. The original understanding of the Constitution was the understanding to which the people gave their democratic consent. Actually, originalists vary among themselves (sometimes within a single text) as to the relative importance of Framers' intent, ratifiers' intent, or "the public understanding of the language" 31 at the founding. Be

26. BERGER, supra note 2 , at 6 . The insistence with which Berger invokes the interpretive purity of speech to defend originalism is noteworthy:

The historical records here relied on-the legislative history of the Fourteenth Amendment-are of a far more trustworthy character, being a stenographic transcription of what was said in the 39 th Congress from day to day by those engaged in framing the Amendment. It is a verbatim account of what occurred, ... comparable to a news film of an event at the moment it was taking place and free from the possible distortion of accounts drawn from recollection or hearsay. What men say while they are acting are themselves facts, as distinguished from opinions about facts.

Id. (emphasis added).

27. Richard A. Posner, Law and Literature: A Misunderstood Relation 218 (1988) [hereinafter POSNER, LAW AND LITERATURE] ("A legal intentionalist holds that what you are trying to do in reading a statute or the Constitution is to figure out from the . . . available information how the legislators whose votes were necessary for enactment would probably have answered your question."); $c f$.

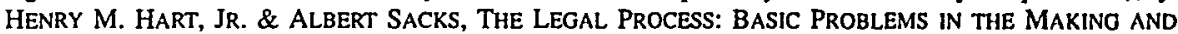
APPLICATION OF LAW 1374-80 (William N. Eskridge, Jr. \& Philip P. Frickey eds., 1994) (describing similar hypothetical-dialogue model). Posner acknowledges that how the Framers "would probably have answered your question" will often be indeterminate, leaving judges to rely on "political" and "ethical" considerations. Richard A. Posner, Legal Formalism, Legal Realism, and the Interpretation of Statutes and the Constitution, 37 CASE W. RES. L. REV. 179, 214 (1986) [hereinafter Posner, Legal Formalism).

28. POSNER, LAW AND LITERATURE, supra note 27 , at 240.

29. See, e.g., BORK, supra note 1, at 159-60; POSNER, LAW AND LITERATURE, supra note 27, at 228-29.

30. See, e.g., BERGER, supra note 2, at 364; Meese, supra note 2, at 20.

31. Henry Paul Monaghan, Stare Decisis and Constitutional Adjudication, 88 CoLUM. L. REv. 723. 
that as it may, the basic claim is that the "original intent" is or may be deemed to be "the sense in which the Constitution was accepted and ratified by the Nation.",32 Thus intentionalists will claim that their reading of the Constitution embodies "the fundamental will of the people," and that a "Jurisprudence of Original Intention ... reflects a deeply rooted commitment to the idea of democracy." 33 Non-originalist interpretation "violates the basic principle of government by consent of the governed." 34

In this rather obvious way, originalism rests on premises concerning the demands of self-government, premises conforming precisely to the model of speech. Democratic legitimacy requires that constitutional law conform to a mental state (original intent or understanding) ascribed to the governed (through the consent expressed by ratification) at a specified time (the founding).

It follows that interpretation must be a matter of allowing the democratically authoritative speakers to speak their minds. Anything else would introduce judicial intermediation between the governed and the government. In the "verbatim" records of their debates, says Berger, the framers of the Fourteenth Amendment left behind a "'iranscript of their minds." "35 Adhering to this unmediated expression of the authoritative mental states is self-government; anything else is "government by judiciary."

But originalism is not the only method of constitutional interpretation animated by a past-oriented speech modeling. Consider the other strategy of so-called strict construction-literalism, or "plain-meaning" interpretation, which under Justice Scalia's tutelage is becoming a little more presentable these days. ${ }^{36}$ Surely this most "textualist" of interpretive methods must be the opposite of what I have called speech-modeled interpretation. How better to honor the writtenness of a text than to adhere to its every letter?

The literalism of plain meaning, its concern for the "letter" of the law, is misleading. The signs of the model of speech in plain-meaning jurisprudence are apparent just below its appeal to the written word of a legal text. Why do plain-meaning advocates so frequently tell us that the words of the Constitution

725 (1988). Bork makes a similar argument:

Though I have written of the understanding of the ratifiers of the Constitution. . that is actually a shorthand formulation, because what the ratifiers understood themselves to be enacting must be taken to be what the public of that ume would have understood the words to mean. It is important to be clear about this.

BORK, supra note 1 , at 144 .

32. BERGER, supra note 2, at 364 (quoting 9 JAMES MADISON. THE Wrmings of JAMES MAdison 191 (Gaillard Hunt ed., 1910)).

33. Edwin Meese, Speech Before the American Bar Association (July 9. 1985), in ThE GrEat Debate: INTERPRETING OUR WRITTEN CONSTITUTION 1. 9 (Federalist Soc'y ed.. 1991)

34. Berger, supra note 2, at 296.

35. Id. at 372 (quoting Charles Sumner) (emphasis added). (1989).

36. See, e.g., Antonin Scalia. The Rule of Law as a Law of Rules, $56 \mathrm{U}$ CHI L. REV 1175. 118. 
"say what they say,"37 that "when the Constitution says $x$, it means $x, " 38$ or that the Court must not invalidate federal or state statutes unless "the Constitution clearly speaks"? ?9 To anthropomorphize a writing is not to treat it as writing, but to speechify it: to treat it as if it had a voice or an intent of its own, as if it were somehow speaking its own mind. Nor is clarification by question and answer absent from literalist interpretation. It reappears when plain-meaning judges consult their Webster's.

Ultimately, the literalism of the plain-meaning school represents an effort to satisfy both the present- and past-oriented ideals of the model of speech. The claimed justification for plain-meaning interpretation is usually twofold. On the one hand, what a judge identifies as a law's plain meaning will often be said to be the best evidence of legislative intent. Here, the conceptual apparatus of "plain meaning" is precisely that of "plain speech." When this justification is relied on, the interpretive goal is a determination of what the legislators meant to say, and plain-meaning interpretation is a species of intentionalism.

On the other hand, the more sophisticated defense of plain-meaning jurisprudence envisions the judiciary entering into a sort of clarifying conversation with the lawmakers today. By taking each law "literally," it might be said, the judiciary sends a message to the lawmakers, demanding that they consider their words more carefully and make better, more particularized, or more accountable choices in the future. Here, a different dialogue is contemplated, a dialogue directed at clarifying and particularizing the lawmakers' present will. On this view, the plain-meaning judge is not insisting, "This is what the legislature clearly intended," but is rather putting a question to the lawmaking body: "Come-is this what you want to say?"

There is nothing illogical about either defense of plain-meaning interpretation, although in constitutional matters both encounter obvious obstacles. The Constitution's language is rarely plain enough to satisfy the goal of determining exactly what was originally intended, and of course on issues of constitutional law, the "legislature" can hardly talk back at all. These few words are not an attempt to disprove what the proponents of literalism claim, that their interpretive strategy offers the most responsible way for the judiciary to keep up its end of the conversation. The question is whether constitutional interpretation is to be viewed as a form of conversation at all.

37. Planned Parenthood v. Casey, 112 S. Ct. 2791, 2883 (1992) (Scalia, J., dissenting).

38. See, e.g., Meese, supra note 2, at 15 ("Where [the Constitution] says that Presidents of the United States must be at least thirty-five years of age, it means exactly that.").

39. Id. at 19. 


\section{The Voice of the Present}

Christopher Tiedeman, an influential legal commentator of the late nineteenth century, wrote that the "binding authority of law . . . does not rest upon any edict of the people in the past; it rests upon the present will of those who possess the political power." And in a democracy, it was "the people of the present day who possess the political power." It followed that originalism was wrong:

It is true that a true interpretation of the law must disclose the real and full meaning of the lawgiver; but in countries in which popular governments are established the real lawgiver is not the man or body of men which first enacted the law ages ago; it is the people of the present day who possess the political power, and whose commands give life to what otherwise is a dead letter. . . Hence, since under a popular government governmental authority rests upon the voice of the people,... that interpretation, in strict conformity with the fundamental rule of interpretation, must prevail which best reflects the prevalent sense of right. ${ }^{2}$

Here is speech-modeled constitutional interpretation conceived on an exact analogy to originalism, except that the judge must determine not what the Framers would have said about the meaning of a constitutional provision, but rather what the people today would say. The "judge . . . who would interpret the law rightly ... need not concern himself so much with the intentions of the framers of the Constitution." recognize the present will of the people as the living source of law, we are obliged, in construing the law, to follow, and give effect to, the present intentions and meaning of the people."st

Tiedeman's conception may seem naive today, both in its assumption of a "prevalent sense of right," and in its suggestion that the judiciary sometimes knows best the true popular will. ${ }^{45}$ But modern scholars recapitulate Tiedeman's understanding whenever they assert that constitutional interpretation should be governed by the nation's current fundamental values. In every formulation used to describe these values-"contemporary norms,"

40. Christopher G. Tiedeman, The Unwrttten Constitution of the UNtred States: A PHILOSOPHICAL INQUIRY INTO THE FUNDAMENTALS OF AMERICAN CONSTIUTIONAL LAW 122 (New York. G.P. Putnam's Sons 1890).

41. Id. at 150 .

42. Id. (emphasis added).

43. Id. at 151 .

44. Id. at 154 (emphasis added).

45. Id. at 164 .

46. Terrance Sandalow, Judicial Protection of Mmoriues. $75 \mathrm{MICH}$. L. REV. 1162. 1193 (1977) ("[C]onstitutional law must now be understood as expressing contemporary norms . ") 
"the fundamental ethos of the contemporary community," held attitudes"

Processualism is another version of present-oriented, speech-modeled constitutional interpretation. According to processualists, the function of judicial review is not to impose "substantive values" on the nation, but to safeguard the process of democratic decision making. ${ }^{49}$

The freedom of speech is (naturally) the exemplary case. As explained by Alexander Meiklejohn, a First Amendment processualist whose arguments prefigured John Hart Ely's more systematic treatment, the Constitution properly secures speech against majoritarian invasion not in order to honor a substantive value like individual self-expression, but in order to ensure the existence of an informed electorate ${ }^{50}$ In this way processualism simultaneously denies not only the (originalist) claim that the substantive decisions of the dead may legitimately govern the living, ${ }^{51}$ but also the (fundamentalist) claim that the judiciary may legitimately "speak before all others for [the people's] constitutional ideals." 52

Processualism regards the entire goal of constitutional law as a matter of letting the people speak for itself. "Self-government is nonsense," Meiklejohn wrote, "unless the 'self' which governs is able and determined to make its will effective."53 For a processualist, judicial review exists to "clear[] the channels" 54 of political communication, to ensure that every citizen has a right to be heard, to see to it that the representatives genuinely speak for the whole citizenry. ${ }^{55}$ The aim of constitutional law is to "structur[e] the government, and to a limited extent society generally, so that a variety of voices would be guaranteed their say." 56

\section{The Voice of the Future}

Earlier we observed the familiar interpretive position in which courts are supposed to give voice to fundamental popular values. The standard objection to this approach is that the people's elected representatives are far better

47. Robert Post, Theories of Constitutional Interpretation, 30 REPRESENTATIONS 13, 30 (1990).

48. Harry H. Wellington, Common Law Rules and Constitutional Double Standards: Some Notes on Adjudication, 83 YALE L.J. 221, 310 (1973).

49. ELY, supra note 3 , at 73-74, 92.

50. See, e.g., MEIKLEJOHN, supra note 16, at 24-27, 39 .

51. Ely quotes Thomas Jefferson: "“[T]he earth belongs in usufruct to the living; . . the dead have neither powers nor rights over it." ELY, supra note 3, at 11 (quoting 5 THE WRITINGS OF THOMAS JefFerson, 1788-1792, at 116 (Paul Leicester Ford ed., New York, G.P. Putnam's Sons 1895) (internal quotation marks omitted)).

52. Planned Parenthood v. Casey, 112 S. Ct. 2791, 2816 (1992).

53. Alexander meiklejohn, Political Freedom: The Constitutional Powers of the People 14 (1948).

54. ELY. supra note 3 , at 105.

55. Id. at 152-67.

56. Id. at 80 (emphasis added) 
positioned than courts to speak for popular values. Fundamentalists have a reply to this objection, but the reply requires them to move beyond the presentdirected orientation with which they usually begin. It requires an appeal to the popular voice of the future.

Alexander Bickel's extremely influential early book. The Least Dangerous Branch, provides an illustration. In the much-quoted passage stating the "counter-majoritarian difficulty," \$7 Bickel identifies democracy with governance by the present will of the people. "[D]emocracy," he writes, "mean[s] that a representative majority has the power to accomplish a reversal." 58 When the Court strikes down legislation, "it thwarts the will of representatives of the actual people of the here and now .... That, without mystic overtones, is what actually happens." 59

It did not follow, however, that judicial review was necessarily illegitimate. Two hundred pages later, Bickel concludes that judicial review can yet be justified if judges, insulated from political pressures, "immerse themselves in the tradition of our society" and base their decisions on the "fundamental presuppositions" that reflect the "morality" of "our tradition." But how could this appeal to tradition be justified given the present-oriented understanding of democracy with which Bickel began? His solution lies in the future.

The hinge of the argument is Bickel's claim that the Court can shape popular will: "The Court is a leader of opinion, not a mere register of it ...." If the Court exercises its leadership effectively, today's countermajoritarian decision may yet receive tomorrow's stamp of popular approval. Accordingly, although ostensibly giving voice to traditional morality, the Court should "declare as law only such principles as will-in time, but in a rather immediate foreseeable future-gain general assent." The Court must be "at once shaper and prophet of the opinion that will prevail." Shaper and prophet: The Court may speak for the people's constitutional ideals, but it may do so only if as a result the people comes to affirm the ideals to which the Court gave voice.

Although Bickel himself came to mistrust it, ${ }^{\text {tid }}$ his justificatory turn to the future has been repeated by numerous fundamental-values proponents, including Justice William Brennan. ${ }^{65}$ Thus a futurist fundamental-values

57. BICKEL, supra note 4 , at $16-17$.

58. Id. at 17.

59. Id.

60. Id. at $236-37$.

61. Id. at 239.

62. Id. (emphasis added).

63. Id.

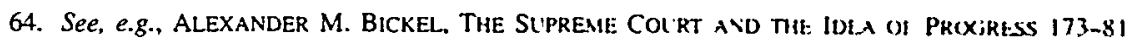
(1970).

65. See William J. Brennan, Jr., The Constitution of the L'nited States Contemporary Ratutication. Speech to the Text and Teaching Symposium at Georgetown Unusersty (Oct 12. 1985), in IVTERPRETI G 
approach to constitutional interpretation turns out to occupy the final available temporal position in the punctuated temporality created by the model of speech. Taking this future-perfect perspective, the Court need not assert that the people's elected representatives failed to represent their constituents accurately. On the contrary, the Court will have forged a consensus that did not exist at the time of its own decision, and this future vox populi will retroactively ratify the Court's departure from then-contemporaneous majority will.

\section{The Impasse of Time in the Model of Speech}

From conservatism to activism, from the jurisprudence of strict construction to that of fundamental values, today's prevailing accounts of constitutional interpretation share a common structure. They seek to make constitutional law the echo or harbinger of a vox populi-which never has been or will be heard. Rousseau was right: The voice of the people is in fact the voice of God.

But I have not yet offered an argument against speech-modeled constitutional interpretation. What I have said so far proves only, at most, that partisans of originalism, processualism, or fundamentalism must recognize that they are all making essentially the same case for their respective interpretive positions. All want the Constitution interpreted as a vehicle for popular voice. The difference among them lies chiefly in their temporal orientation.

This means, however, that the partisan of speech-modeled interpretation must choose one temporal orientation over the others. On what ground can he make this choice? Within the model of speech, can one of the three available temporal positions claim to honor some constitutional value that the other two infringe?

Each can; that is what proves fatal. American constitutionalism cannot be forced into any of the speech-modeled slots without essential loss. As a result of its tripartite temporal equivocation, the model of speech can never do justice to constitutional law.

Let's begin again with originalism. When called upon to defend the claims of the past, will the originalist say that the Framers were far wiser than we, or

\footnotetext{
THE CONSTITUTION, supra note 2, at 23, 25, 33 (first asserting that in every "act of interpretation . . . it is, in a very real sense, the community's interpretation that is sought," but then explaining, as to his vicw of the death penalty, that even though he differed from the majority of Americans, "I hope to embody a community striving for human dignity for all, although perhaps not yet arrived") (emphasis added); see also Post, supra note 47, at 28, 30, 34 (first asserting that the judiciary's task in interpreting the Constitution is to "uncover" present values and to "speak for the ... ethos of the contemporary community," but then claiming that "the national ethos . . . may in significant ways be affected by" judicial decisions, and that "a court can, through the eloquent articulation of public ideals, actually help to solidify a national ethos").
} 
that past intentions are for some reason superior as such to present ones? Originalists do not typically make these arguments.

Originalists rarely challenge the supremacy of present popular will, if expressed through the constitutionally requisite amendment procedures. Their only point (they will say) is that judges have no business amending the Constitution. "We remain entirely free to create all the additional freedoms we want by constitutional amendment." electorate but judges," there can be no "departiure] from the actual Constitution." Judges must not "revise the Constitution." ${ }^{\circ 6}$ In other words, when judges depart from the original intentions, they no longer interpret or apply the law. They have become lawmakers. ${ }^{69}$

Let's separate the good from the vacuous in this logic. When originalists defend originalism with the truism that judges lack authority to amend the Constitution, they beg the question. They presuppose that only originalism produces legitimate or correct constitutional interpretations (otherwise they would be unable to count departures from original intent as acts of judicial revision). But that is the question at issue.

Interpretive positions such as Tiedeman's, Ely's, or the early Bickel's make equally vigorous claims for the legitimacy of their interpretations. Each denounces the originalist's bugaboo, "rule by judges according to their own desires."70 Each maintains that the voice of the people should be paramount. Once the speech-modeled premises of all these positions have been laid bare. the originalist must say why the voice of the past furnishes the only correct or legitimate basis for interpreting the broad or ambiguous language of the text. "Because judges have no business amending the Constitution," no matter how many times originalists say it, only begs that question.

At this juncture, an originalist might be tempted to say something about institutional competence. Inquiring into (past) legislative intent is something judges are trained and well suited to do. By contrast, trying to speak for today's people, to say nothing of tomorrow's, is something judges are utterly unsuited for; let elected representatives do that.

This line of reply has some truth in it, but its logic at this point in the argument is unsatisfactory. We can easily posit conditions in which current popular will (accepting arguendo this figure of speech) is judicially known or knowable-through polls, countrywide legislation, and so on-as well as, if not better than, the will of the "Framers," particularly given the notorious difficulties in defining that term. It is perfectly possible, for example, to

66. BORK, supra note 1 , at 171.

67. Id.

68. BERGER, supra note 2 , at 289.

69. See, e.g., id. at 288-99; BORK, supra note 1. at 143-55. 160. POSVER. LAW' AND LTTERATR RE, supra note 27 , at 229.

70. BORK, supra note 1. at 160 . 
imagine one lone state holding out against all others in maintaining an antiabortion law in a pre-Roe or post-Roe nation. But originalists don't want courts to be free in such circumstances to strike down the dissenting state's statute on the basis of contemporary fundamental values. (They want to say: If voters today support a constitutional right to abortion, let them enact one.) And their reason is not solely the slippery slope. Their reasons are deeper.

When originalists talk about judges becoming lawmakers, they are making a claim about the demand for stability in law. Non-originalist interpretation, they say, "convert[s] the "chains of the Constitution' to ropes of sand."" Taken on its face, this claim is hard to understand. As noted above, any number of non-originalist interpretive positions could claim for themselves the virtue of producing stable constitutional doctrine. ${ }^{72}$ But from the perspective of the model of speech, strict constructionists see only one possible interpretive strategy, broadly defined, other than their own: allowing the judiciary to speak for the nation's constitutional ideals, whether on the basis of a supposed present consensus or a supposed future consensus. This strategy, as originalists see it, allows constitutional law to vary far too much. "[A]n activist jurisprudence . . . is a chameleon jurisprudence, changing color and form in each era." ${ }^{13}$ In this form-as an argument within the model of speech-the originalist's claim finally has some force.

Within the model of speech, the voice of the past embodies the value of law. The rule of law demands that there be rules known or knowable in advance, rules neutrally enforced and applied in like cases alike. To an originalist, judicial speculation about today's or tomorrow's popular opinion would turn constitutional law into something like a weather forecast. There would be no constitutional law at all. Thus can Bork write of his jurisprudence of original intent:

If the Constitution is law, then presumably its meaning, like that of all other law, is the meaning the lawmakers were understood to have intended .... There is no other sense in which the Constitution can be what article VI proclaims it to be: "Law.",74

Once again, taken at face value, the assertion is false. It is not the case that "all other law" has for its meaning the meaning that "the lawmakers were understood to have intended" at "the time of the law's enactment." Th5 oldest law of all - the law of custom-is not enacted by any lawmakers. Hence customary law (and much of the common law was just that) cannot be said to

71. BERGER, supra note 2, at 371 .

72. See supra part II.B.1.

73. Meese, supra note 2 , at 20.

74. BORK, supra note 1 , at 145.

75. Id. at 144 . 
mean what "the lawmakers were understood to have intended." Even with respect to statutes, the meaning of the law will frequently accrete through a common-law process, defying so narrow an intentionalist reduction. ${ }^{76}$

But take Bork's assertion within the perspective of the model of speech. If judges genuinely interpreted the Constitution according to present popular will, or according to some ever-shifting future popular will, they would undermine the Constitution's legality. To say so is not to give credence to an ideal of stability for stability's sake; it is not to presume a certain ideological conservatism, however much that predilection might underlie actual originalist commentary. It is rather to recognize that the Constitution, to be what it has always been understood to be in America, must bind. A constitution bending with every turn in popular will is in a sense no constitution at all, if by a constitution we mean something with the force of law-law capable of restraining popular politics as well as creating the institutions for its exercise.

Against this emphasis on law, how would partisans of the present voice of the people defend their position? They will lay claim to a different value, one equal if not superior to legality in constitutional affairs: the value of selfgovernment itself.

Every present-oriented version of the model of speech ultimately rests on the claims of the living to govern themselves. Tiedeman made this point repeatedly, ${ }^{77}$ and it appears early in Ely's book as well. ${ }^{78}$ But even originalists tend to concede the supremacy of present political will. When strict constructionists excoriate judicial activism, they do so on behalf of the right of voters today to make their own political decisions. And when originalists are pressed hard about the problem of the past will governing today, they respond by suggesting that the Constitution as originally adopted retains the consent of the people today unless or until the Constitution is amended."

The model of speech inexorably presses the demand for self-rule toward the voice of the present. Ideally, the will directing the state would never have to be yesterday's; the citizenry would be able to gather on a moment's notice and issue an up-to-the-minute declaration of its authoritative will. As Rousseau put it:

76. A notorious example is the Sherman Anutrust Act. IS U SC $\$$ (1988) "Today the Act means. not what its framers may have thought, but what economists and economics-minded lawyers and judges think." Posner, Legal Formalism, supra note 27, at 209: of. Rober H Borh. Legislatrve Intent and the Policy of the Sherman Act, 9 J.L. \& ECON. 7 (1966).

77. See supra notes $40-44$ and accompanying text.

78. See supra note 51 and accompanying text.

79. This appears to be the import of Bork's present-tense clam that "/s]ocicly consents to be ruled undemocratically within defined areas by certain enduning pnnciples placed beyond the seach of majorities by the Constitution." Rober H. Bork. Neutral Principles and Some First Amendment Problems. 47 IND. L.J. 1, 3 (197I) (emphasis added); see also BORK, supra note I. al 171 Obviously. Ihis impliedconsent-through-failure-to-amend argument is a thin reed on which to rest the onginalist case. given the super-majoritarian obstacles to amendment posed by Article V See Akhul Reed Amar. Phuladelphua Revisited: Amending the Constitution Outside Artucle V. 55 U. CHI. L. REV 10-13, 1072 (1988) 
Now the general will that should direct the State is not that of a past time but of the present moment, and the true characteristic of sovereignty is that there is always agreement on time, place and effect between the direction of the general will and the use of public force ... ${ }^{80}$

In the circumstances of an interrupted polis-in the circumstances of constitutional democracy as perceived by the model of speech-there may be three temporal orientations for constitutional interpretation to adopt, but there remains only one ideal source of political legitimacy. That source is the constitutional voice of the people, fully and immediately expressed, at the moment of political decision itself. Within the model of speech, the voice of the present is the voice of self-government.

And the future? Can a partisan of the voice of the people to come invoke yet another cardinal constitutional value, omitted or given short shrift by those who press for past-established law or present-tense self-government? The answer is as well known as the other two we have just described, and it appears, implicitly or explicitly, whenever someone appeals to the future in constitutional interpretation. Bickel called it "the idea of progress." ${ }^{81}$ Justice Brennan invoked the image of a "shining city upon a hill." ${ }^{\text {" T2 }}$ The voice of the future carries with it a promise, if not of perfection, then at least of something more perfect than what went before.

Again some effort is needed to separate out the good from the bad in this claim. How exactly is the voice of those to come equated with a better or higher state of earthly affairs? Does the claim rest on a myth of special American destiny, some narrative of national ascent, according to which future popular will or values (if only they could be known) would be automatically entitled to deference when compared to those that came before?

Perhaps such mythologizing is a necessary concomitant of a future-oriented approach to constitutional interpretation. If that were all there were to the futurist's position, it would be about as persuasive as the counternarrative of national descent, the countermyth of the Framers' godlike greatness, their wisdom and high-mindedness, which Americans will never again attain. But mythology is not the only framework within which to understand the futurist's claim.

It is hardly credible, after all, that Justices of the Supreme Court could accurately foretell what the popular view of any constitutional matter will be in the future. Or that there will be only one future view. Or that the Court could deliberately and successfully create a lasting national consensus on

80. Jean-Jacques Rousseau, On the Social Contract or Essay About the Form of the Republic (Geneva Manuscript), in ON THE SOCIAL CONTRACT 157, 168 (Roger D. Masters ed. \& Judith R. Masters trans.. 1978).

81. BICKEL, supra note 64.

82. Brennan, supra note 65 , at 33 . 
constitutional issues significantly disputed today. Perhaps, however, the futurist's best defense is not that he is trying to say what the voice of the people to come will in fact be. Perhaps his point is that, within the model of speech, a judge who acts without regard for the voice of the future is omitting an essential ingredient of constitutional interpretation.

The Constitution does not merely recite, in the way of some older English analogues, rights said to have been enjoyed in the past, whose contours are therefore to be sought in still more ancient texts and practices. The Constitution is aspirational. It sets down what were, in important part, at the time of the writing, new institutions and rights, to be henceforth enjoyed, as against the institutions, injustices, and abuses of previous governments. It initiated a project for the realization of new freedoms and new equalities in American society.

Blind obedience to the voices of the past and present cannot capture this constitutional striving. A judge who insisted solely on either the compulsion of past understandings or the compulsion of present will would have forgotten the ideal of a more perfect union that underlies the entire document. This element of constitutional interpretation can be found, the partisan of the future suggests, only by asking what people will say tomorrow of what we do today. Judges needn't pretend to know what will be said or to be able to shape what will be said, but they must yet ask the question; they must orient their decisions toward the imagined judgment of a future that has overcome today's backwardness and condemned the evils that are today accepted as ordinary or inevitable. Within the model of speech, the voice of the people to come represents the voice of justice.

The ultimate problem with the model of speech is not, therefore, that it fails to supply any reasons for choosing one among its three temporal orientations. The problem is that it supplies too many.

Democratic legitimacy lies in a confluence of just these three factors in the state: legality, popular rule, and justice. Written constitutionalism is an effort to join these values in a single, temporally extended practice. But the model of speech disjoins them, splitting each from the others in a tripartite temporal schism. A partisan of the past, present, or future can equally claim that only his temporal orientation makes good on an integral constitutional value. This is why modern constitutional law, still dominated by the model of speech, seems always open to, and yet radically torn among, the ideals of law, majoritarianism, and justice. The model of speech wants all three, but cannot have one without sacrificing the others.

Speech-modeled interpretation can deliver a fixed Constitution, presenttense self-government, or a vision of justice. But it can never do justice to constitutional self-government. 


\section{Where Writing Was, Voice Will Be}

It is not fortuitous that the punctuated temporality of the model of speech should find constitutional self-government forever eluding its grasp. The model of speech is bound to set the Constitution, as a writing, in opposition to selfgovernment. This opposition manifests itself in the suspicion or disregard that every speech-modeled interpretive position displays for the Constitution as a writing.

For the intentionalist, the Constitution never says enough. Here is Posner on the Cruel and Unusual Punishments Clause of the Eighth Amendment:

Particularizing would not only have been time consuming but also might have sparked debilitating controversy, since it is easier to agree on generalities than on particulars. ... "Sufficient unto the day is the evil thereof" might be the motto of the legislative process. The forging of consensus, or even just majority agreement, in a diverse group may be impossible unless some disputes can be papered over with general language, leaving resolution to the courts. ${ }^{83}$

Posner is making important concessions here; he is acknowledging that an inquiry into original intent will not exhaust a court's role in adjudicating Eighth Amendment claims. Observe, however, the qualities of compromise, deficiency, and even duplicity imputed to the text in this analysis. More particularized language would have been the superior result, but the effort to achieve particularity might have ended in no law at all, revealing the true disagreements that general language was able to cover up. Hence the high principles of the Constitution come into being-and the necessity for interpretation begins - when ideal speech gives way to a "failed" duplicitous writing: when true intentions are not voiced but "papered over."

And when true intentions are voiced in the course of the enactment process, originalism finds the text still more deficient, paling by comparison to the "transcript of their minds" that we find in the records of what the Framers said. For the originalist, the constitutional text might have a certain eloquence, but it presents woeful inadequacies when regarded (and judges must so regard it) as an attempt by the Framers to speak their minds. The text is a place holder here: It is merely "evidence" of the law. Thus hollowed out, the constitutional space can be filled instead with acts of speech, real or hypothetical, attributed to the Framers.

By contrast, for processualists, the Constitution says too much. As even Ely concedes, some of the most important provisions of the Constitution cross

83. Richard Posner, Interpreting Law, Interpreting Literature, RARITAN, Spring 1988, at 1, 14.

84. Posner, Legal Formalism, supra note 27, at 190 ("Judges should ask themselves . . . : what would the framers have wanted us to do in this case of failed communication?"). 
the line from safeguarding democratic processes to imposing substantive values. ${ }^{85}$ Such provisions must be marginalized; they must be treated as exceptions to the one "function" that is "appropriate to a constitution": that of allowing today"s citizens to have their say.

Why? Because the processualist does not recognize any democratic justification for allowing the voice of the dead to make substantive decisions for us. Even the guarantee of equal protection, the single most important substantive principle of justice in the Constitution, has to be hollowed out, reduced to a processual principle under which slavery instituted for purely utilitarian reasons would apparently be perfectly permissible. ${ }^{57}$ Here, too, the text is hollowed out, but now in order to fill the constitutional space with the voice of the people today.

By the time we come to the fundamental-values approach, the Constitution no longer says much of anything. It is up to judges to "speak before all others for [the people's] constitutional ideals," as the Court wrote in Casey," even if the ideal so voiced has virtually no connection to the text at all.

Professor Post, advocating this interpretive position, has had the courage to acknowledge what has become of the text here. If the purpose of constitutional interpretation today is to predict and forge tomorrow's popular voice, then the Constitution itself "loses its character as a specific document or a discrete text." ${ }^{\prime \prime 9}$ Instead it functions at best as a benevolent yearning, "the "imaginary focus from which the concepts"' of constitutional adjudication "seem to proceed, even though there is nothing knowable at that focus."

These various interpretive positions share a common aim: to reduce the written to the spoken, to turn a commitment to writing into a poor vehicle for voice. And this is to be done, in every case, in the name of self-government: specifically, in the name of a speech-modeled ideal of self-government, with which a written constitution is invariably a compromise.

Isn't it just possible that the Constitution might be better understood, better interpreted, not as a deficient act of speech, but as a monumentally successful act of writing?

85. See, e.g., ELY, supra note 3, at 94. 98 (acknowledging that Religion Clauses and Thirtecnth Amendment protect what Ely calls substantive values).

86. Id. at 100; see also id. at 88-101 (attempting to show that Constutution. With feu exceptuons, is "pnncipally, indeed I would say overwhelmingly, dedicated to concerns of process")

87. Ronald Dworkin observed this apparent consequence of Ely's analysis 10 years ago See Dworkiv, supra note 4 , at 68 .

88. Planned Parenthood v. Casey, 112 S Ct. 2791. 2816 (1992)

89. Post. supra note 47, at 24.

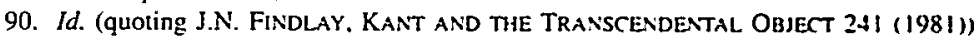




\section{E. Conclusion}

Plenty of writings exist for which speech-modeled interpretation is perfectly proper. When there is no privileged text to be worked through or marveled over; when the language to be understood is not set in stone, but is rather a vehicle for the expression of a speaker's mental state; when what is sought is not interpretation at all, but clarification-speech-modeled interpretation is entirely apt.

Ultimately, then, the question is whether the Constitution is the sort of text properly subjected to speech-modeled interpretation. Occasionally, commentators will raise or glimpse the possibility that the Constitution might call for a mode of interpretation distinguishable not only from intentionalist interpretation, but from every other speech-modeled interpretive method. Where this question has been raised, however, the animating thought has been that the Constitution might profitably be compared to literature. Thus one reads that a Shakespearean sonnet might be a useful point of departure for reconsidering constitutional interpretation, ${ }^{9 !}$ or that judges ought to regard constitutional interpretation as a sort of "chain novel." The claim in such cases may be either that constitutional interpretation has more in common with literary interpretation than is supposed; or that all interpretation, properly analyzed, is ultimately more like literary interpretation than is supposed.

The strength of the law-and-literature movement has been its effort to move legal interpretation beyond the model of speech. (Dworkin specifically criticizes what he calls "conversational interpretation" as a model for law. ${ }^{93}$ ) Its weakness has been a propensity to replace the model of speech with equally inapposite models of writing. The idea of judges as literary critics or "chain novelists" does no more justice to the Constitution's writtenness than does the idea of judges as "platoon commanders" receiving half-transmitted orders in the field of battle. ${ }^{94}$ What is needed in constitutional interpretation is a textualism aspiring to neither the mystery of literature nor the transparency of literalism. What is needed is a new textualism, which takes as its starting point the central role of a written constitution in democratic self-government.

If self-government ideally consisted of governance according to the will of the governed, then ideally what we would seek in our constitutional law-to the extent that we sought legitimate constitutional law-would be the voice of some set of authoritative democratic speakers, expressing the popular will in the immediacy of some authoritative democratic moment. We would want our

91. See Charles Fried, Sonnet LXV and the "Black Ink" of the Framers' Intention, 100 HARV. L. REV. 751 (1987). For an influential essay offering the view that constitutional law ought to be regarded as "a branch of literature," see Sanford Levinson, Law as Literature, 60 TEX. L. REV. 373 (1982).

92. RONALD DWORKIN, LAW'S EMPIRE 228-38 (1986).

93. See id. at $53-65$.

94. See Posner, Legal Formalism, supra note 27, at 189-90, 199-201. 
written constitutional text to disappear or dissolve itself into this voice. We would want no constitutional text at all, and constitutional interpretation would attempt as best it could to replace the text with the relevant acts of speech. We would read the Constitution as spoken.

To read the Constitution as written is to leave behind the idea that selfgovernment is government in accordance with the will or consent-with the voice - of the governed. Democracy in America is not classical democracy. Reading the Constitution as written requires that we recapture the radical departure in democratic thought marked by American constitutionalism.

\section{Self-Government OVER Time: The MOdel OF Writing}

For two thousand years, political theorists in the West explored various possible constitutional forms, but no political typology-indeed no politics at all-applied to constitution formation. Aristotle, for example, who classified constitutions according to whether they vested governance in the one, the few, or the many, ${ }^{95}$ had no theory differentiating constitutions according to whether they had been made by the one, by the few, or by the many. No linkage existed between constitutional form and constitutional formation, at least no linkage such that an ideal democratic constitution, say, would have had to have been the product of a democratic politics. On the contrary, politics could take place only after the constitution-the politeia-was in place. If, before America, political liberty could have been thought to require a democratic constitution, democracy was never thought to require democratic constitution formation.

The eruption of written constitutionalism in late eighteenth-century America broke from this two-thousand-year history. It made constitution formation a constitutive element of political freedom itself. It made constitution writing part of the very idea of democratic self-government.

It is not merely convenient that the United States Constitution is committed to writing. Writtenness was a specific ingredient of America's constitutional revolution because what written constitutionalism overturned, when it brought constitution formation into the picture of constitutional thought, was the speech-modeled conception of democratic self-government.

When a people writes rather than speaks on fundamental matters, the polis is no longer the proper image for a vision of democracy. The model of speech - with its demand for the implementation of a given moment's popular will-speaks for a different and outmoded political temporality. It cannot grasp a constitution's temporal extension, which is to say its writtenness. It has no conceptual resources by which to comprehend how a nation can govern itself over time.

95. See ARISTOTLE, THE Politics 96 (Carnes Lord trans., 1984) 
Written constitutionalism breaks from the premise that self-government ideally consists of government by the will or consent of the governed at any given moment. It begins rather with the idea of self-government as a temporally extended project.

What would we say about self-government if we thought of it as temporally extended?

\section{A. The Freedom To Write}

Nothing a people can do can be done in a moment. The foundational acts by which self-government is to be measured-the establishment of certain liberties or institutions, the eradication of certain political or social evils, the creation in large or small part of whatever constitutional vision animates a people's foundational law-take generations to accomplish. Political liberties and institutions do not even exist at a given moment, but only through a complex, extended set of events. If we ask, "Is this people a self-governing people now, at this moment?", we ask a question that cannot be answered.

An individual may imagine that his freedom consists in living each moment according to his then-present will. He might, in other words, aspire to live without law (except that this aspiration would itself figure as a kind of law). But for a people, lawlessness is not even imaginable.

A society without law is possible, but it would not be a human society: of ants or angels, perhaps, but not of men. And if a people cannot do without law, then self-government cannot be conceptualized as the achievement of a state of affairs in which the then-present voice of the people (or the majority) governs at each successive moment. Democratic self-government demands-in its ideal, rather than as a compromise with that ideal-not only authorship of the law but constraint by it as well.

Isn't the same true, at the end of the day, for individual self-government? Here we touch on the meaning of human freedom; let's say what we can, assuming the risks. The model of speech accepts the notion of freedom in which a person is ideally free if he acts, or is free to act, as his own free will directs at each successive moment. Of course morality may always impose supervening duties on a person, but as to freedom itself, it is his voice alone that ought ideally to dictate. (Only a situation in which a person's will is overborne, like Odysseus in earshot of the sirens, would justify the subordination of present voice.) As a result, no matter how much stress the model of speech lays on human beings' ability to engage in rational discussion, speech-modeled thought ultimately equates human freedom with animal freedom: the freedom to act on current will.

Kant argued two hundred years ago that true human freedom could not consist in acting to satisfy desires, but had to consist instead in acting 
according to rules divined from a priori reason alone. ${ }^{*}$ Speech modelers often struggle with this concern, trying to temper their apparent reduction of freedom to willfulness by insisting that what should govern is only the rational or deliberate will, the will that has been purified of distorting, transient passion. ${ }^{97}$ But the model of speech has no basis for privileging passionless, rational, or deliberate will over its opposite; and even if it did, it would have cut out its eyes to save its face. Passion is indispensable to self-government. The demand for freedom or justice is itself a passion; keeping certain passions in power is part of the project of constitutional self-government.

Suppose, then, that we retained the first part of Kant's argument, but rejected both his noumenal world (in favor of the temporal one) and his rationalizing impulse as well. Suppose we said that the distinctly human ability is the capacity to relate to oneself as a temporally extended self, the capacity to hold oneself to a purpose or ideal over time instead of following at each moment the pull of that moment's dominant desire. This is the capacity that allows human passion to be more than animal desire. This is what justifies, if anything does, our according ourselves a right to life that we deny to animals.

All sorts of animals have desire; all sorts of animals have will. Some can speak. But no animal except man, it seems, has more than the most abecedarian capacity to conceive of itself as a temporally extended being, to lay down and adhere to temporally extended objectives and thereby to leave a mark on the world. No animal but man can write.

Self-government among human beings is not achieved by attaining that "state of grace in which . . the voice of authority is nothing other than the voice of the self." 98 This is the state of grace enjoyed by stray dogs, in which no authority directs the agent's action except the agent's own will. Selfgovernment is achieved by committing oneself to certain ends and holding oneself to those commitments over time. Human freedom is the freedom to write: to give one's life a text.

Or at least this is so in the domain of the political. If our polity were genuinely governed by current popular will or popular consent at each successive moment (assuming that such a thing could occur and without mentioning the text that would be necessary to identify the decision-making people), what pride would we take in this animal legitimacy? We are 100 large and too heterogeneous a people to sustain a particularized consensus for long. We would lurch from one endeavor to another, accomplishing nothing. We would know no law and do no justice.

96. See immanuel Kant, Groundwork of the Metaphysic of Morals 1 I +21 (H J Paton trans. Harper \& Row 1964) (1948).

97. See, e.g., ACKERMAN, supra note 15. at 272-74, 285-88: TIEDEMAN, supra note to, at 108-09. $162-64$.

98. KAHN, supra note 5 , at 8. 
To this impasse-the sacrifice of legality, justice, and accomplishment to the demands of a supposed legitimacy-a final paradox would have to be added. On the terms prescribed by the model of speech, speech-modeled selfgovernment could in fact never be achieved. Even if a people deliberated as a single body and spoke with one voice, ratifying a perfectly rational plan of action, the moment the people left off deliberating to begin acting on the plan, it would be putting into effect a past decision without consulting its present will. Government can no more have the consent of the governed than the hare can overtake the tortoise.

All the temporal impasses produced by applying the model of speech to self-government-with the seeming result that a people can never govern itself, or can never do so under law, or can never do so justly-are Zenonian. They belong to the category of paradox produced whenever something whose temporal extension matters is analyzed as if it existed or took place in momentary time slices, each of which is conceived as instantiating the whole in infinitesimal part.

Self-government is possible-indeed intelligible-not in the momentary time slices of speech-modeled consensualism, but only over time. The Constitution did not express the will of the American people as of the moment of ratification. The people did not issue its 1789 consent, to be measured against its consent of 1790,1791 , and so on from year to year, or moment to moment, from that time on.

Through the Constitution, the American people initiated a written commitment to certain institutions and principles. Holding ourselves to those commitments, despite our contrary will at various subsequent moments, defines the project of reading the Constitution as written.

The decisive terms here are "people" and "commitment." Let's address the meaning of those terms.

\section{B. Popularity}

If self-government is a generation-spanning project, there must be a generation-spanning subject of this project. This subject I call a people.

On the one hand, the idea of an inter-generational "people" is well known to American constitutional thought. The Constitution seems to claim such a people as its author. ${ }^{99}$ Originalists, too, claim that they are honoring "the fundamental will of the people," 100 which means that the people today has been identified with the people that enacted the Constitution.

On the other hand, everyone knows that "the People," understood as an entity transcending particular individuals alive at any one moment, died long

99. See U.S. CONST. pmbl.

100. Meese, supra note 33, at 9; see BERGER, supra note 2, at 296. 
ago, just a little after God did. The benighted enlightenment, which brought God low, raised the People to His majuscular place, only to suffer His fate. Who today speaks of "We the People," other than demagogues, originalists, and Yale law professors?

The American people will seem an utter mystification so long as we believe that individuals must know one another through face-to-face interaction in order to constitute the kind of group that could be an authentic political community; or that individuals cannot form such a group unless they share a high degree of homogeneity in their values, interests, or way of life; or that, to be a people, individuals would have to partake in a general or common will. But these are speech-modeled criteria. They boil down to the familiar perception that members of a national people must, metaphorically if not literally, "speak the same language."101

If we do away with these speech-modeled criteria, we open a space for a demystified people conceived on the model of writing. Not an organic body politic, but a Madisonian people embracing innumerable and even violently conflicting interests. A people defined as nothing more or less than the temporally extended set of persons who belong to a given society.

This formulation doubtless raises more questions than it answers. I will try to amplify below, but I by no means pretend to offer a full account of what it means to be a people. Our concepts in this field are too impoverished; English doesn't even have a word designating the condition of being a people, as "personhood" does (and "personality" used to) the condition of being a person. In the following discussion, I use "popularity" to describe this condition. Whatever labels are used, to say with confidence what a people is, one would have to be able to say with confidence what a person is. I confess in advance that I can do neither.

This much is clear: We are looking for criteria of popularity in a constitutional sense. That is, we want to know what sets of persons can be agents of constitutional self-government. So, for example, while it may be coherent, if insidious, in some conversations to refer to the white or black "people," that sort of popularity is unacceptable here. There is no such thing as the white people of the Earth, or the black people, in a constitutional sense, and there could not be without some cataclysmic global changes. For a set of

101. See, e.g., D.J. KotzE, NATIONALISM: A Comparative Study 4-5 (Henn Snujders trans , 1981) Kotzé's astonishing declaration reads:

The members of a people speak the same language. .

.. I know of no instance where all members of a people do not use a partucular language or closely related dialects, although it may of course happen that more than one people regard a certain language as their mother tongue, as in the case of Spanish and English. Id:; see also ERNEST GELLNER, NATIONS AND NATIONALISM $109 \mathrm{n} .1$ (1983) (statung that members of a nation "“speak the same language" even when they do not speak the sime language") On the importance attached to a common language by various nationalist movements over the last 150 years, see generally BENEDICT ANDERSON. IMAGINED COMMUNmES 67-154 (rev. ed 1991). 
persons to be the agent of self-government, they must at least coexist in a more or less identifiable social setting; they must belong to a going society.

For the same reasons, when I say that a people consists of the members of a given society, I am not referring to high society or the Society of Elks. Society is to be defined for constitutional purposes in terms of persons living under a legal order. Not because law makes a people the kind of people it is (in that respect, law is merely one societal product among others), but because law is what makes a people $a$ people. Law sires peoples.

What makes a people $a$ people is not to be found in some homogeneous culture, shared values, or shared language. If Americans have been a people distinct from the Canadian people, it is not because we have thought, acted, or spoken in some quintessentially different way from Canadians. Defining popularity in terms of homogeneity is the first sign of speech modeling (the second is defining popularity in terms of what individuals say or would say when asked to define themselves). What has distinguished our nation, our people, from theirs in the constitutional sense is nothing other than the reach of the Constitution itself.

To make popularity dependent on the reach of a legal order is to recognize that in a given case, it may not be possible to say with certainty whether there is a people in existence at all (or whether there is more than one). This will be true not only in certain primitive societies, but also in certain highly developed ones, where, for example, there may be several subordinate legal orders within a larger one. In fact, given a certain degree of development of the institutions of international law, it will be perfectly possible to speak of an international or even a global people, at a time when smaller, national peoples remain in place. But a definition can be only as definite as the phenomenon it defines, and a people never exists at a single moment, no more than a country exists at a single place. Law is a temporally extended phenomenon-a law applied only for one moment would not be a law at all-and there is no popularity without law.

To recognize the determinative role of law in popularity is also to recognize that peoples are born in chains. The law that brings them into being is not of their own making. Political freedom consists of a people's struggle for the authorship of its own legal order.

Let's consider two objections to this discussion.

"First," one might say, "your definition of a people is much too thin a frame on which to drape the heavy fabric of selfhood necessary to the idea of inter-generational self-government. Surely at a minimum you need a society in which individuals strongly identify with the collective enterprise, and in which they relate to one another with a great deal of solidarity. A people of self-interested individuals can hardly be a people at all, if 'people' is to have your thick, inter-generational trappings." 
"Second," one might object, "your talk about a people 'committing itself" to something reintroduces the mystification or mythologization that your definition of popularity is supposed to avoid. How can a people commit itself to anything without precisely the kind of general will or collective mind that you claim to be avoiding?"

These two objections, although not mutually exclusive, point in very different directions.

The first would likely be offered by a communitarian, anxious to save the ideal of a relatively tightly knit community existing and governing itself as a body politic. The problem with my account of popularity, from this point of view, is that I reduce peoples too far into constituent atoms. I have made individuals the ultimate political matter, and I haven't even had the sense to insist that they be bound together in tight molecular structures in order to count as peoples.

The second objection would more likely be offered by a liberal, inclined to reject altogether the idea of peoples as the subject of self-government. Only persons exist, not peoples, and the best or truest self-government would be that of an individual governing himself. ${ }^{102}$ The problem with my account of intergenerational commitment, from this perspective, is that the agent or subject of this commitment is a myth, a reification. I have treated what is at best a wavelike epiphenomenon-a manifestation of forces propagating through the true political matter, the individuals-as if it were a thing in itself.

In making objections of this kind, both the communitarian and the liberal refuse to let go of the old, speech-modeled dichotomy between individuality and popularity, between the sovereign voice of the individual and that of the people. They remain stuck in the pointless duality that has characterized so much political theory for such a long time, insisting that political matter must consist either of self-interested persons or public-minded peoples, but not both.

If we want to move beyond this duality, we have to move beyond the thought that makes will the defining trait of political subjects. Will occupies a central position in the model of speech: Will is what is to be voiced and what produces an entitlement to be heard. Every individual should have a say, the liberal variant goes, because every individual has his own, independent will; and a people exists as a sovereign body, the republican variant goes, when there comes into being that collective or majority will which the vox populi expresses, or at the very least when there comes into being that degree of mutually perceived interdependence which allows the inner voice of each

102. John Stuart Mill writes:

[S]uch phrases as "self-government" . . do not express the true state of the case The "people" who exercise the power are not always the same people with those over whom it is exercised. and the "self-government" spoken of is not the government of each by humself. but of each by all the rest.

JOHN STUART MILL, ON LiBERTY 12 (Elizabeth Rapapot ed.. 1978) (1859). 
to become inextricably interwoven with the public discourse of all. In either the liberal or the republican case, freedom consists of being able to voice the relevant will and of being subject to no authority other than this voice.

If, by contrast, we began with the thought that human freedom lies distinctively in the ability to write, we might then define a political subject not as any being with a will, but as any being with the capacity to formulate purposes or principles to which it holds itself, as against the exercise of momentary will, over time. Such purposes or principles would occupy the same definitive position in the model of writing as will occupies in the model of speech. They are what is to be written down; they are what entitles their holder to participate as author in a project of self-government. And it would follow that peoples are as much political subjects as persons are, because a people may have legible principles even if it does not have a vocable will.

Within this distinction between principle and will, will is determinate. It relates to particular circumstances, and it desires particular outcomes. In the speech-modeled ideal, the relevant will would be completely determinable: Every outcome it desired would be fully specifiable, and for every possible set of circumstances, it would have a desired outcome. These determinate coordinates would define, as it were, the "position" of the relevant bit of political matter.

I suspect that an uncertainty principle quite as rigorous as any that applies to atomic particles applies to the human will, preventing the position and the trajectory of any bit of human matter from being precisely determined at the same time. In any event, in a society such as ours the people has nothing resembling a positional, determinate will; what is positional and determinate at most is the will of various individuals. A people such as ours has no determinate position of the sort that would allow it to speak its mind. It has no mind of the sort that can be spoken.

It may, however, have principles and purposes. Principles and purposes are general, not determinate: They relate to numerous contexts and provide guidance about how to act in these contexts. This is the level at which a people's individual constituents may find common ground. There may well be a broad overlapping of the principles to which individuals want their nation to adhere, even if there is confusion when it comes to saying what those principles require in particular circumstances. Such shared principles form the basis of a constitutional commitment.

"But you still have no ground at all for ascribing these principles to your people. This 'people' doesn't 'have principles'; individuals do. To move from an overlapping of individuals' principles to the idea that the 'American people' has principles that 'it' might pursue over time is at best a figure of speech or at worst a mystification."

In this objection, Marxists, communitarians of conservative or progressive stripe, and liberals might all agree. None believes, after all, in a heterogeneous 
national people; none believes in the American people. For the Marxist or communitarian, citizenship in a big, divided society of self-interested individuals is a sham; the "people" in such a case is a myth, a figment of the imagination. The liberal agrees with this conclusion, adding only that a big. divided society of self-interested individuals is all a nation can ever be-and all we ought to want it to be.

It is difficult to escape the speech-modeled thinking that pits individual self-interest against political community as an opposition of individual versus collective identity, interest, or self-definition. But we have labored with this thinking for too long, when it cannot do justice to America. It makes us deny our own history; it makes us disbelieve in ourselves. We need to be prepared to think of persons and peoples in a new way.

Why is it tempting to say that a people of individualists or of divided subcultures is not a subject in itself? On what ground do we so confidently attribute a unity or at least a subjectivity in such a case to persons, but deny it to the people?

It's obvious, I suppose it will be said: Peoples are composed of all sorts of opposing and hierarchized wills and viewpoints. True, but aren't the psyches of what we call individuals composed of countless impulses, views, thoughts. feelings, in tension or even opposition with one another, some of them subject to stern repression?

"But an individual's impulses and feelings are linked in a single body," it will be said. True, but those of a people are linked in a single territory and a single society.

"But a person's impulses are linked in a different way: by neurons that make them all part of one brain." True, but what neurons do is communicate, and the various persons that make up a people can communicate among themselves too.

"But a person has a will, don't you see? He makes a decision eventually. His inner conflicts are conflicts interior to a single consciousness and a single mind. He speaks, in the end, with one voice."

Is this so? Whether it is or isn't, peoples too can make decisions. When a matter is decided by vote, and the entire group acts thereafter on the vote, who made the decision? To be sure, group decisional processes can be described as the making of a series of interdependent individual decisions, first in the vote and subsequently in the individual decisions to go along with the vote. Such a description, however, would leave us wondering who made the decision-the one that was followed.

"There was no "the decision," the answer might be; "that's the key myth. Whenever anyone says, 'we decided,' he is the victim of a delusion or at best is using a figure of speech. There are always only coordinated individual decisions." But doesn't this answer leave something out? Is it really the fact of the matter that there was no group decision, but only a network of 
individual decisions? Isn't it simpler and equally true to say that the group of persons decided what it would do?

And what if it turned out that a person's decisions could be redescribed in analogous fashion, as a weighing-in of a number of voices, a sort of majority vote being taken, and an acquiescence of the contrary voices to the majority? Or to go further: What if an individual's decisions could be redescribed as the operation of electrical and chemical forces disseminating through his brain? In either case, wouldn't it still be simpler and equally true to say that the individual decided what he would do?

I think we have to be as prepared to think of peoples (or families, for example) coming to life, surviving over time, making decisions, taking actions, and dying, as we are of persons. We should be prepared to do so as long as we do not suppose that a people making a decision or taking an action-such as committing itself to a written constitution-consults or expresses a positional, collective will.

A people so conceived is not antithetical to individuality. Only through membership in a people can individuals be self-governing, for no individual but a king-and perhaps not even he-can make law for himself. In this respect individuals owe their freedom (if they have it) to their people, but a people owes everything else to individuals. A people cannot experience the world, make decisions, take action, flourish, or suffer except through individual subjectivity. Individual heterogeneous minds are a people's only points of access to the world and its only source of the decisions, principles, and passions it requires in order to be a self-governing subject, an end in itself. The for-itself-ness of a people, to use an old philosophical idiom, depends entirely on that of the individual minds of its members. For the people to be an end capable of self-government, its members must be ends; and a state that failed so to treat its citizens would transgress against that alone that makes government legitimate.

There is one final objection to be considered. "Your head is so far in the clouds," someone might say, "that I can't even see you. Tell me again how 'the people' committed itself to the Constitution in 1789. I must have missed something. Tell me again how 'the people' committed itself to government of the people, by the people, for the people, way back then. I see people in chains. I see blacks, Indians, women, and poor people dehumanized and disenfranchised."

The exclusion of the majority of persons alive in the 1780's from the constitution-making procedures of that period eats away at the foundations of the Constitution's legitimacy. From the consensualist viewpoint, it ought to undercut the legitimacy of ratification altogether. No majority in any of the thirteen states consented to the Constitution in 1789; at best a majority of the white, propertied males did. 
If the legitimacy of the Constitution had to be secured at a single moment, its legitimacy could not be secured at all. This conclusion holds for 1789 just as much as it does for today. But commitmentarianism, unlike consensualism. as we shall see, does not look to one moment to ground the Constitution's bindingness and accordingly does not try to bury the past or to mythologize it.

There was a people that in 1789 initiated a commitment to the constitutional order: a people definable more or less as white, male Americans. This people did not exist as a natural kind. It owed its popularity to a legal order that differentiated it in crucial ways from other members of American society more broadly defined. And this people instituted something like selfgovernment for itself through the Constitution, as Athenian citizens achieved something like self-government for themselves while keeping slaves and excluding women from political activity. But neither ratilication by this American people, nor the constitutional commitments begun by ratification, could possibly claim to be legitimately binding on individuals kept in thrall to a separate legal order and denied membership in the self-governing people. If, for example, the slaves in some region had risen, seized land, and established their own sovereign nation, they would surely have had the principle of selfgovernment (as well as justice) fully on their side.

Let it be said in defense of the white, male Americans who enacted the Constitution, that it was their people, and the very commitment to selfgovernment that they undertook, however viciously some of them abused it, that in large part destroyed slavery and radically renewed the Constitution's legal order, expanding its membership across the boundaries of race, gender, and wealth, over the next two centuries. In fact, we are obliged to say something stronger. The people of America today is the people of white, male Americans who founded the Constitution in 1789. That people grew into this one; for better and worse, we are they.

No individual citizen today, appealing to the color of his skin, to gender, to religion, or to ethnicity, can say, "My people never voted for any constitution." Peoples are defined by the force of law that gives societies their order, and not by any of these invidious criteria except to the extent that a legal order invidiously incorporates them. But the legal order that established slavery and denied women basic rights has been largely dismantled, and the peoples created by these regimes no longer exist. The Constitution's people opened itself to them, and they, for better or worse, to the Constitution.

At a constitutional convention in 1789, it was possible, even predictable, for a delegate to refer to the "hordes of Africans" "infestling] my region," and of course it remains possible for racists today to speak of black Americans as not belonging to the American people-although it happens that the diatribe just quoted was made in France, not America, and the reference was to Jews. 
not blacks. ${ }^{103}$ Today we are all Jews and blacks; we are all minorities infesting a region that some other set of persons would like to have for itself. Like it or not, however, we are all also members of a single historical people, all taking part in America's sins and glory. A Jew whose ancestors arrived here in 1904, and even a black whose ancestors were carried here in 1804, has an equal responsibility to say, "It was we who kept slaves," but also an equal right to say, "It was we who fought for freedom."

In the end, it doesn't matter what we say to ourselves. We have no more choice about the people into which we are born than we do about our family or body. While we speak, and regardless of what we say, a people of Americans is writing itself into history, the land its palimpsest, and we ourselves its characters.

\section{Commitmentarianism}

Suppose, then, that an American people did and does exist. Suppose, despite everything, that this same people ratified the Constitution and continues to live under it today. Aren't we still obliged to understand the Constitution's claim to bindingness through the concept of consent, whether past, present, or future? And if so, don't we necessarily fall back into the model of speech, with all its temporal disjointedness?

What we are looking for is a normative operation that does not crystallize authority in a single moment, thereby setting past, present, and future at odds. We are looking for a normative operation irreducible to an act of will at any particular moment.

This normative operation is commitment. Commitment, not consent, is the normative force through which the Constitution exercises binding authority. By commitment, I mean an undertaking made in exercise of the freedom to write. A commitment is a holding of oneself, against day-to-day interest and even against will, to something that gives purpose or meaning to one's life: for example, to a goal, a relation with another, a principle, a profession, or a cause. A commitment engages. It projects one's life onto a given course, the path and ultimate destination of which are never fully known in advance.

Now, most constitutional commitments differ from most personal commitments in several respects. They are polygraphic: written and subscribed to by many hands, not by one. They are foundational: laying down new, basic structures and principles that had not governed before. And they are political: the product and producer of institutions wielding the forces of law and state. Thus while personal commitments are analogous to constitutional commitments, they are not identical, and while I will use examples of personal commitments to illustrate the differences between consent and commitment,

103. See PAUL JOHNSON, A HisTORY OF THE JEWS 306 (1987). 
these illustrations will mislead if they slight the differences between the personal and the constitutional.

Commitment departs from consent along four main axes: in the time required to bring it into being; in the manner in which it exercises normative force; in its relation to the unknown; and in its proper method of interpretation.

\section{Time Taken}

It takes only a moment to consent. The ideal of consent is speech-modeled through and through: A perfect act of consent expresses a mental state in existence at the moment of expression and permits something to be done on the basis of the consenting party's own will. Situated thus in the momentary temporality of the model of speech, consensualist justification always has to choose from a familiar tripolar menu of options. It may look either to an act of authoritative past consent, to present consent, or to some kind of predicted consent. Once again, the choice among these three options will reflect, respectively, the values of legality, self-rule, and justice.

A commitment, however, cannot be achieved in a moment. One may decide to commit oneself to something on any given day. But saying doesn't make it so (even if the saying is in writing). Only time will tell if there is in fact a commitment.

In other words, commitment requires more than decision. One commits oneself to something, in the first place, through a commitment of temporal resources-a piece of one's scarce time on earth. A relationship must be lived with, a principle lived under, before one can genuinely call oneself committed to it.

This means (dangerous as it may be to recognize it) that a written constitution cannot claim its full authority immediately upon ratification. There will be a period when only the weaker claims of consent can be made for it: weaker precisely because of the temporal limitations that attach to obligation by consent. If a majority has or even may have changed its mind (if a particular vote in convention, for example, was quite close), there will be no reason of legitimacy (although there may be reasons of stability) why the consent of the past should continue to govern.

Unlike a contract entered into in a going legal regime, a written constitution cannot at the moment it is concluded plant its feet on the ground of law to sustain the authority of past consent over the claims of present will. The reason of course is that the constitution itself - at least a foundational one like ours-will have founded the legal order in which the relevant act of consent has legal force. The early intimations of state secession in 
America ${ }^{104}$ were not shocking betrayals of the cause of self-government. The right of self-government, when consent is all it has to sustain it, can never deny the ultimate supremacy of present will. Had the First Congress promptly declared war on England and France, would it have been plainly illegitimate if several states withdrew from the infant nation, despite their recent vote to join it? And had Congress then called on the militia to suppress what it deemed the insurrections in the seceding states, which party would have had legitimacy on its side? Neither, then; only heaven and time would have told.

This is why the longer a set of constitutional commitments has been in place, the more weight it has. The authority of the past, understood within the model of speech, has to crystallize in a single mythic moment of constitutional consent. The authority of a past commitment, by contrast, gains power as it endures over time.

This does not mean that we should adhere to the Constitution solely because it is old. In order for constitutional commitments to endure, they will have to be true to the people that lives under them. An individual might conceivably live a whole life under a commitment false to himself. But a people, according to every great mind to have explored the subject, will not long endure such a constitution. Polygraphy is not infallible, but every constitution must pass its test; the holding power of our Constitution is good reason to believe that its principles are, or have come to be, our principles. If so, then we ought to adhere to them.

For all this, however, the longevity of a constitutional commitment also provides a demand for its own reexamination. The essential thing is that some constitutional commitments-some set of foundational political precepts and institutions-be given a chance to be realized. Otherwise there is no selfgovernment at all, but only willfulness. Once they have had their chance, however, the same demand for self-government that gave these commitments authority demands their reassessment, to ensure that they remain commitments the people can recognize as its own. The endurance of particular constitutional principles will always carry both a positive and negative sign: positive because what has endured has proven itself to be capable of enduring, and negative because in this proof there will have come into being realities, rather than mere abstract formulations, that will not measure up to the ideals of which the original formulations were an expression.

104. See, e.g., 1 H. Von Holst, CONSTItUTIONAL AND POLITICAL History OF tHE UNITED STATES 143-67 (John J. Lalor \& Alfred B. Mason trans., Chicago, Callaghan \& Co. 1889) (1875) (discussing Virginia and Kentucky resolutions of 1798). 


\section{Binding Force}

The obligation entailed by an act of past consent does not require, on the part of the consenting party, any continuing recognition of the value of that to which consent was given. In other words, you can experience the force of your obligation in the following terms: "I gave my word, and I'm obliged to honor it, fool that I was to have given it."

Is it possible to understand a self's dedicating itself to a principle (with no promises made to any other party) through the concept of consent? This is to ask whether self-government, insofar as it involves obligations imposed by $a$ self solely upon itself, can be intelligibly conceptualized as a matter of consent. The answer is probably yes. Even in the case of an individual, the force of a self-imposed obligation to adhere to a principle can be experienced as grounded in consent. You might say, "I promised myself I would abide by this principle, and I owe it to myself to carry through." The self is subjected here to a moral schizophrenia ("I promised myself"), in order to create a recipient of the decisive act of consent.

There is, however, another way in which your resolution may exercise force. It may recall you to yourself. It may oblige you, force you, to acknowledge what you once believed to be right and then embarrass you in your temptation to depart from it. In the first case you felt obliged to keep your word even if that word had been foolishly pronounced. In the second you feel obliged to honor a commitment you still recognize as your own. In the first, you imagine yourself temporally split into the subject and object of obligation. In the second, you re-collect yourself over temporally distant moments.

This form of bindingness creates a necessary conditionality in principle of any commitment to principle. We remain bound to our principles only so long as they remain our principles, only so long as we continue to be able to regard desires to act contrary to them as error, selfishness, or the like. We are always free, that is, to say, "Yesterday I knew nothing; my principle was misguided." Whatever authorized us to make a legitimate demand on ourselves in the first place equally authorizes us to remake the demand today. To say otherwise would require invocation of something like a principle that demanded adherence to past commitments, right or wrong; but then this principle would remain binding upon you only so long as it remained your principle.

In practice, this principled escape clause from our commitments is easily transformed into a complete subversion of them. We can always say, "I've arrived at a new principle," when in fact what we propose is simply unprincipled. Or, "What I propose to do is perfectly consistent with my principle," when in fact what we propose is a blatant violation of it. In any event, each person is ultimately judge of his own case, free to tell himself any story he can make himself believe. Such is the embarrassment of morality-but 
also its nobility, for one who remains true does so knowing that the rest of us will be false, and that our falsity will be utterly unaccountable, here or hereafter, inside or out.

But these remarks may occasion two doubts. First, what work is being done by the commitment here at all, if in the end the principle (the object of the commitment) must continue to be held in order for the commitment to hold? Second, haven't I now conceded that commitmentarianism is as presentoriented as any speech-modeled position? Haven't I in effect acknowledged that a people remains bound by its constitutional principles only so long as it currently consents to them?

These two objections are related. There is an initial, obvious answer to the first question, and then a more important point that responds to both. To begin with the obvious: We are concerned here with constitutional commitments, and because the Constitution is polygraphic, it follows that from the point of view of any individual, it is the commitment as such, not the merit of the principles or institutions framed by the Constitution, that does the binding. When you make a New Year's resolution, you are free at any future moment not only to break it, but to repudiate it: to decide as a matter of principle that the resolution was a bad one. But no individual may change his mind about the Constitution; it is not his mind to change. An individual is bound to the Constitution not insofar as he personally accepts it, but insofar as he is a member of a people committed to this legal order.

This much, we should observe, does not differ significantly from what a consensualist would say about an individual's relation to the Constitution. On the usual consensualist view, the individual is not bound as a matter of his own personal consent, but as a matter of his membership in a people, a majority of whom consents. The problem for the consensualist is (as we know) that what should be binding is not the Constitution we have, but the constitution to which the American people (or a majority thereof) would consent today, if each had his say and all had an opportunity to arrive at a deliberate decision. This brings us to the second objection raised above, to the effect that understanding the Constitution as commitmentarian is presentoriented after all.

Nothing could be further from the case. If commitmentarian selfgovernment demanded that a people attempt every day to discern the principles it holds most deeply and to try to enact these principles into law, then commitmentarianism would be as present-oriented-and as steeped in temporal antinomy - as any speech-modeled position. But self-government demands that a people must precisely not try to do this every day.

The speech-modeled mistake lies in supposing that self-government would ideally exist if only we could reach and implement today a deliberate majoritarian decision about every aspect of our constitutional law. To repeat: A people who achieved this state of grace would find the ideals of law, self- 
rule, and justice at war with one another. Such a people would be merely willful, not self-governing. True self-government requires a generationspanning effort and therefore some temporally extended commitments.

This means that a people's temporal constituents-its "generations"-stand in a relation to the Constitution similar to one obtaining between a people's geographical constituents-its cities or states-and the Constitution. Just as a given state is bound by the Constitution's commitments as such, not by the merits of the principles committed to, so too a given generation ought to look upon the commitments themselves as an independent source of normative force.

We who live today could not achieve self-government by enacting a new constitution perfectly congruent with our collective will (even if we had a collective will). We are beneficiaries and trustees of American self-government and all its freedoms, purchased at great cost. If we must reject those freedoms as a matter of principle, we must. But the great betrayal of the cause would be to jettison history in favor of "our" freedom. Human freedom is historical; it is the freedom to write. "Our" texts would have to project themselves upon future Americans in order to have any effect at all. The necessary temporal extension in all efforts at self-government gives each American generation a responsibility to carry on the work of the past, and to tear down the current edifice only in conditions of greatest need.

In this way, commitmentarianism supplies a stronger defense of supermajoritarian requirements for constitutional amendment ${ }^{105}$ than consensualism can. A pure consensualism must condemn the amendment procedures laid out in Article V; in fact it ought to demand the kind of facilitated, majoritarian amendment procedure ${ }^{106}$ that threatens the entire project of constitutionalism. By contrast, self-government on the model of writing demands that constitutional amendments be made not whenever a majority so wills, but only when the people is prepared to make a significant temporal commitment to them, and a supermajority requirement is one method of ensuring that this condition obtains.

In the end, however, every people is free to tear down its monuments. But the ultimate openness of a commitment today does not make commitmentarian self-government present-oriented. When a people decides between holding to its current foundational law and embarking on a new constitutional path, it is not facing a choice between submission and freedom. Either course will be an effort to participate today in a necessarily temporally extended project, involving both freedom and submission. Neither will guarantec selfgovernment; never can it be said with certainty, at any one moment, that a people is self-governing here and now.

105. See U.S. CONST. ant. V.

106. See, e.g., Amar, supra note 79 , at 1064-66. 
Thus the way a constitution binds a people is not the same as the way it binds individuals, states, legislators, judges, presidents, and so on. The Constitution binds these parties in the strictest sense; they have no authority to violate or revise the Constitution, whether they like it or not. The Constitution binds the people in a different sense; it does so as the spine of a book binds its pages. It gathers individual upon individual, generation after generation of Americans, into a single political subject. A constitution's ultimate success and normative force depend on whether it works as a means of recalling a people to itself over time-a means by which the people recollects its temporally extended self.

\section{The Unknown}

Consensualist justification becomes more perfect to the extent that the consenting party knows exactly to what he is consenting. In the ideal state of affairs, what is being done to the consenting party would conform exactly either to what that party knows himself to be consenting to now or to what he knew himself to have been consenting to at some prior, authoritative moment. (Hypothetical consent is always a worst-case option for a purely consensualist theory of justification.) Consent must be knowing; in the ideal, it should be fully informed.

Suppose that you have been asked to consent to something; that you contemplate certain specific sets of facts arising; that you talk through these eventualities with those who have asked for your consent; and that, at the precise moment of consent, you are knowingly consenting only to certain quite specific obligations in the event these facts arise. Should they indeed arise, your consensualist obligation-the obligation completely justifiable by reference to your consent-will be solely the obligation to which you knew yourself to be consenting. To be sure, someone may yet insist that your act of consent should be deemed sufficient to force upon you something to which you did not knowingly consent, on grounds (for example) of reliance, assumption of risk, or public policy. But these justifications are non-consensualist, and they would be necessary to supplement the imperfect consensual obligation.

In other words, you cannot (to use Ronald Dworkin's terminology) legitimately be said to have consented to a "concept," rather than a "conception," 107 unless the claim is as a factual matter that you were consenting to submit to an interpretive process in which a different "conception" of the "concept" might be held against you. If in fact you understood yourself not to be consenting to any such process (if you had a determinate idea of what the consented-to thing entailed and never intended to submit to anybody else's interpretation of it), then the claim that you were

107. See Ronald DWorkin, Taking Rights Seriously $131-49$ (1977). 
consenting to the concept, not to a conception, would be a sort of trick. You did not in fact consent either to the substance or to the process.

Thus within consensualism, the meaning of a consented-to principle ought ideally (to achieve perfect obligation) to be nothing other than the particularized understanding of the requirements of the principle held by the consenting party at the time of his consent. From a pure consensualist viewpoint, the content of a person's consent-what he consented to-is not contained in anything external to him, but in his mental state at the time he consented. What is not known to the consenting party at the time of consent is alien to his consent and, should the unknown materialize, tends to undermine its normative force.

By contrast, the unknown is inscribed in the very structure of commitmentarian obligation. A commitment is a self-imposed obligation to be bound by requirements that are, at least in part, derived externally from the mind of the one who makes the commitment. A commitment always carries with it the possibility that what one has in mind at any given moment, past or present, about the application of the commitment to particular facts may be wrong.

Certainly this is so in the case of foundational commitments, such as those enacted during our two great periods of constitution making, the 1780's and 1860 's. These commitments projected the nation into a previously untried legal order; the individuals who frame enactments of this kind have not themselves lived under the institutions and legal rules that are to follow from them. It is not a question here merely of encountering unforeseen developments. It is a question of understanding the normative requirements of a new set of political relations and principles. These requirements cannot be fully known in advance, even if every relevant development has been accurately foreseen. They cannot be knowledgeably assessed except by living under the new institutional and legal principles, and seeing how they work themselves out in practice.

No one can know what a fundamentally new principle or institution genuinely requires of him before he has lived under it. Commitmentarian obligation is an obligation to see something through: to live up to responsibilities as they develop in actual fact, even if the commitment is not ultimately absolute, and even if those responsibilities prove at times to be unexpectedly onerous.

The consensualist aspiration to perfect congruence between ex ante expectation and ex post obligation may be coherent, but it has little to do with the normative structure applicable to foundational commitments, even those made by individuals when they take actions that project their lives into a new direction-as when, for example, a person has a child. The responsibilities undertaken through such a commitment may or may not have been anticipated by the person beforehand. But his duties do not and cannot wholly depend on what he said to himself about these responsibilities beforehand. 
This is not a normative predicament to be deplored. It is to be embraced as an element of the exercise of human freedom. We are most free not at the moment when we act according to rules consented to in advance with perfect foreknowledge of what they will require, nor at the moment when there is no constraint preventing us from perfectly satisfying a present desire, but when we make and live up to commitments in the face of the uncertain future that these undertakings will bring into being. Such uncertainty is part of the structure of a commitment. Its effect is not to nullify the commitment, but to necessitate a task of interpretation irreducible to a clarification of intent or will: an ongoing task of interpreting the commitment's requirements as it is lived out, which cannot be exhausted by what anyone, not even the maker of the commitment himself, said or would have said yesterday, today, or tomorrow.

\section{Interpretation}

Imagine that, having witnessed some vivid episode of betrayal, you resolve never to lie. You even write this principle down and post it somewhere conspicuous. Some time in the future, you find yourself in a situation in which your silence would allow another person to remain under some impression, while speaking out would cost you something you value considerably. You wonder whether your resolution against lying countenances silence in these circumstances.

Perhaps an intentionalist reading of your text occurs to you: "I'm sure if someone had asked me at the time I wrote this resolution down, I would have said that in these circumstances, only an affirmative misrepresentation would count as lying." Or even: "I distinctly recall saying to myself, originally, that silence would never count as a lie."

Assume that these statements about your past mental state are accurate. If you take your obligation to be consensual, then you could plausibly say to yourself that the intentionalist interpretation of your rule is a legitimate one-an interpretation, that is, perfectly consonant with or true to your obligation, because the limits of your obligation could be defined as nothing more or less than what you meant to be consenting to at the moment you gave your consent.

There is, however, another way to read what you wrote, and this other sort of interpretation may occur to you without your choosing to engage in it. You have just been assuring yourself about your original intentions when a certain doubt is introduced, quite apart from or even against your will, by that faculty in yourself that exercises the power of judgment. The doubt does not concern the accuracy of your memory of your earlier mental state. The question is rather whether, in this case, adverting to original intent is just another excuse for doing what you want to do in any event. 
How could that be, and what happens when this "faculty of judgment" suggests an interpretation of your text different from both your present will and what you had in mind at the time you set it down? What is happening, whether in articulate or intuitive form, is interpretation on the model of writing: an inquiry not into what anyone said or would have said about your rule, but into the rule itself-into the meaning and value of the temporally extended commitment to which you are trying to adhere.

If, reading yourself as committed, you sought to determine in good faith whether or when silence counts as lying, you would have to try to decide what is wrong with lying-what merited your commitment in the first place. You would probably reflect on the episode that actuated your resolution. You might also reflect on the consequences that have resulted from your adhering (or failing to adhere) to your principle in the period since you originally laid it down.

Ultimately you would have to interpret not only the principle but your own commitment to it: that is, you would have to try to determine what you are against when you are against lying, even if someone else might be against something else. Already, in this trivial example, you would be engaged in a process of interpreting your own past and present in a certain light in order to decide how to project yourself into the future-a process of re-collecting yourself over time in light of a temporally extended commitment that you have undertaken.

What you said to yourself at the time you initiated the commitment may be relevant to this inquiry, but it cannot be dispositive: not only because you could have been wrong at that time, but because the commitment you are interpreting has a temporal extension that defies interpretive reduction to any single moment's state of mind. Only through this sort of re-collective inquiry would you be able to try to decide faithfully what your prohibition demands of you now.

In this way, commitmentarianism resolves the temporal disjunctions created by the model of speech. To adhere to one's commitments is always a matter of following one's own, higher law. It is always a project of recollecting past, present, and future. Under a commitmentarian constitution, the rule of law and the aspiration to justice are joined in a project of temporally extended self-government.

\section{READING THE CONSTITUTION AS WRITTEN}

What are the implications of the shift from speech to writing for constitutional interpretation?

Reading the Constitution as written supplies: (1) a theory of judicial review, together with an account of what is sometimes referred to as 
"unwritten" constitutional law; and (2) an overarching method for reading the constitutional text.

An advance warning: The interpretive method outlined below would not put an end to the Constitution's openness to various interpretations. It is not as if the era of densely reasoned and contested opinions, appealing variously to principles and history, logic and common sense, text and vision, might suddenly be brought to a close. That is a consummation dreamed of only by speech-modeled theories, whose fondest hope is always to bring interpretation to an end.

\section{A. Judicial Review: Unwritten Law}

There can only be one reaction today to a discussion of Marbury $v$. Madison: ${ }^{108}$ not again. Justifying Marbury has been the Sisyphean labor of speech-modeled constitutional scholarship. But John Marshall was right: Only the Constitution's writtenness ${ }^{109}$ - that "irrelevant," that "meaningless circumstance," as our strongest commentators assure us ${ }^{110}$-justifies judicial review.

It will never be adequate to say, with the originalists, ${ }^{111}$ that the Court ought to have rested judicial review on a reading of Articles $\mathrm{III}^{112}$ and VI, ${ }^{113}$ drawing support from The Federalist ${ }^{114}$ or similar sources. ${ }^{115}$ Textualism here is circular. No court can read judicial review into the Constitution without assuming the very interpretive power that is supposed to be at issue. Legislative history cannot cure this problem. The moment a judge introduced evidence of framers' intent to clarify the text, he would already have begged the decisive question.

If Congress or the President, for example, were the authoritative exponent of constitutional meaning, the appropriate interpretive methodology could not

108. 5 U.S. (1 Cranch) 137 (1803).

109. Chief Justice Marshall's opinion for the Court in Marbury referred to the Constitution's writtenness no fewer than eight times. See id. at 176-78.

110. Charles L. Black JR., The People AND THE CourT 26 (1960) (observing that Marshall's opinion in Marbury "made a great deal of the fact that the Constitution is in writing -an obviously irrelevant circumstance"); William W. Van Alstyne, A Critical Guide to Marbury v. Madison, 1969 DUKB L.J. 1, 17 ("That the Constitution is a 'written' one yields little or nothing as to whether acts of Congress may be given the force of positive law notwithstanding the opinion of judges ... that such Acts are repugnant to the Constitution."). Professor Monaghan, while stressing that, historically, "the written quality of the Constitution counted a great deal," nonetheless feels obliged to state that "in theory, it would secm a meaningless circumstance." Monaghan, supra note 31 , at 770 .

111. See, e.g., BERGER, supra note 2, at 355-56.

112. See U.S. CONST. art. III, § I ("The judicial Power of the United States, shall be vested in one Supreme Court, and in such inferior courts as the Congress may from time to time ordain and establish.").

113. Id. art. VI, cl. 2 ("This Constitution, and the Laws of the United States which shall be made in Pursuance thereof . . . shall be the supreme Law of the Land.").

114. See THE FEDERALIST No. 78 (Alexander Hamilton).

115. See PAul Bator et AL., HART \& WeChSLER's THE FEDERAL COURTS AND THE FEderal COURT SYSTEM 8 n.34 (3d ed. 1988); RAOUL BERGER, CONGRESS V. THE SUPREME COURT 198-284 (1969). 
be presumed to be intentionalist. Questions left open by the text might properly be settled by current popular will, or by the President's judgment of the best interests of the nation. Originalism presupposes the supremacy of past democratic will, when of course the supremacy of present democratic will is precisely at issue in considering judicial review. Hence a reference to framers' intent to decide which governmental body is textually entrusted with the interpretive power is not an escape from the problem of circularity. It is a move made within the circle.

Nor will it be adequate to say, with the processualists, that judicial review is justifiable so long as judges merely police the channels of democratic politics; or, with the fundamentalists, that judicial review is justifiable so long as judges merely give voice to the people's own ideals. The model of speech reproduces all its temporal antinomies-or rather initiates them-when it confronts judicial review. The processualist defense of judicial review is too thin. It cannot account for the admittedly substantive nature of certain extremely important constitutional provisions (and more generally cannot explain the bindingness of past-enacted constitutional law). The fundamentalist defense is too thick. It cannot explain why a "bevy of Platonic Guardians"11s is competent to speak for the people (and generally cannot account for its sacrifice of the values of legality and self-rule in favor of this sweeping. judicial law-speaking role).

In their own terms, all these positions fail to solve the "countermajoritarian difficulty." 117 In our terms, they fail because they are trying to solve it. The counter-majoritarian difficulty does not exist. Or rather: It exists, but only on the model of speech.

The Justices' decisions cannot be expected to correspond to a majority vote of the citizenry. That much is obvious, but is insufficient to generate the counter-majoritarian difficulty that Bickel identified and that has hounded constitutional thought before and since. A further "fact" has to be added: that constitutional invalidation, because counter-majoritarian, is counterdemocratic. ${ }^{118}$ This further fact holds only on a conception of democracy that imagines self-government as rule by present popular will or consent. Judicial review, wrote Bickel, "thwarts the will of representatives of the actual people of the here and now"; that is "the reason that the charge can be made that judicial review is undemocratic." 119

Written constitutionalism rejects all this. Constitutional law and judicial review are not counter to democracy. They are necessary to democracy. They are necessary to democracy when democracy has been reconceived on the

116. LEARNED HAND, THE BILL OF RIGHTS 73 (1958).

117. See BICKEL, supra note 4, at 16-17.

118. Id. at 17; see, e.g., SCHAUER, supra note 22, at 40; Graglia, supra note 5. at 37

119. BICKEL, supra note 4, at 17 (emphasis added). 
model of writing: when, that is, self-government has been understood in its temporal extension.

A people gives itself law not only by formally enacting on a given day those commitments to which a current majority declares its fidelity. It does so by living under those commitments for some extended period of time; it does so by living up to those commitments, a temporally extended task irreducible to the ideal of conforming government to a present or past popular will. This endeavor requires both adherence by those who wield political will and interpretation by a body insulated from political will. Judicial review is always a compromise with speech-modeled democracy, but it is integral to democracy on the model of writing.

The initial force of this argument lies in a practical consideration, namely the likelihood that the political branches would be likely to interpret away the Constitution's limitations on them. As Marshall put it in Marbury, vesting Congress with the ultimate interpretive power "would be giving to the legislature a practical and real omnipotence with the same breath which professes to restrict their powers within narrow limits." ${ }^{20}$ But this practical consideration, by itself, does not complete the argument. After all, legislators and presidents are subject to frequent recall and replacement by the people. Their interpretations of the Constitution (so long as the electoral system itself goes unimpaired) will likely reflect current popular judgments about these requirements far better than will the Court's. Thus the claim can be made that even within a commitmentarian theory of self-government, judicial review unjustifiably suppresses the judgment of the best interpreter of commitments - the people itself. At the very least, shouldn't the will of the political branches govern in the great range of issues on which the Constitution does not clearly speak? Surely the argument from writtenness turns out to be a refutation of those judges who see themselves as authorized to "expound" the Constitution, ${ }^{121}$ rather than merely authorized to enforce the letter of the law or its original intent?

The argument from writtenness might produce this result if it were solely an argument about the possibility of a President or Congress seizing dictatorial powers. Fully understood, however, the argument from writtenness can answer these questions--and only the argument from writtenness can answer them-because the answer depends on the logographic shift from consent to commitment.

Unlike governance based on consent, which moves toward unimpeachability as it increasingly conforms to the present will of the

120. 5 U.S. (1 Cranch) 137, 178 (1803).

121. See, e.g., McCulloch v. Maryland, 17 U.S. (4 Wheat.) 316,407 (1819) ("[W]e must never forget, that it is a constitution we are expounding."). One holding of $\mathrm{McCulloch}$ was that states could not tax federal instrumentalities, a proscription nowhere expressly set forth in any provision of the constitutional text. 
governed, governance based on commitment becomes impeachable precisely when interpretive questions are referred to the will of the governed. Commitments lose their force to the extent that they are subject to interpretation by those who made them. That is why individual morality and conviction are so consistently feeble: Our tendency to rationalize, our capacity for self-deception, and our general lack of character all conspire to make us the least-reliable interpreters of our own commitments.

Even ideally - even with "electronic town meetings" as participatory, enlightened, rational, open, and thorough as one could desire-it still would not follow, from the commitmentarian perspective, that the tinal arbiter of constitutional meaning should be the people itself, much less the people's political representatives. The people has the absolute right to amend, alter, and abolish, but it has no right to interpret. That would make the people judge in its own case. It would render constitutional commitments as feckless as New Year's resolutions.

If a commitment demands sacrifice, as all commitments worth making do. it does not follow that the only one who may legitimately discharge the interpretive task is the one who bears the commitment's burdens. On the contrary, the great advantage of a constitutional commitment (over a merely personal commitment) is the ability to institutionalize the interpretive power: to delegate this power to a body of persons designed to be neither a proxy for the people as a whole, nor vested with the political power that is chicfly to be restrained, nor reliant on majority will.

This point is in part a variation on the argument from practical necessity. Allowing the people to be judge in its own case would, as a practical matter, tempt the people to violate the Constitution's terms just as allowing legislatures or presidents to interpret the Constitution would likely tempt these political actors, sooner or later, down the same road. But there is another side of this point as well: a deontological side.

The ultimate reason why the people may legitimately be denied the day-today interpretive power under a written constitution is that the people does not exist on any given day. If the people as a temporally extended whole could somehow declare at one moment, in one voice, its interpretation of its own commitments, this impossible declaration would be supreme. But a temporally extended being cannot speak, as it were, all at once. The people as a whole can only inscribe itself, over time, into the world. Constitutional interpretation on the model of writing is itself a written project; it cannot be reduced to a clarifying pronouncement by any set of speakers, even one pronounced in unison by the majority of all living citizens.

The citizens alive at any one moment are not the people as a whole. If a majority vote by today's voters could be said to produce or reflect the popular will, then this will would be but one of several competitors for political power. The voice of the present majority (if there were such a thing) has a better 
claim to democratic authority than the voice of their representatives, but neither constitutes a vox populi supreme in its authority. The people as a whole has a right not to have interpretation vested in the majority of the citizens alive at any particular moment, just as it has a right not to have the interpretive power vested in those exercising the powers of governance. Constitutional adjudication by majority vote would erase the distinction between constitutional commitments, which are temporally extended, and political will, which exists at a given moment-the distinction on which all written constitutionalism is based.

Some kind of judicial review is, therefore, the first law of written constitutionalism, and it is an unwritten law. Because the judiciary cannot derive judicial review from the Constitution's text, all American constitutional law depends on the judicial enforcement of an unwritten constitutional right (the right to a judicial determination of the constitutionality of state action). The necessary extra-textuality of Marbury does not, however, open the door to every unwritten right deemed by five Justices to reflect fundamental or immemorial values. But it does mean that we have to reject the strict constructionist claim that the judiciary never has authority to enforce an unwritten constitutional right. At the same time, it points the way to a general account of unwritten law under a written constitution.

Where law is understood solely as an act of will by the sovereign or by the sovereign's representatives-where, that is to say, law is understood to be whatever the lawmakers say it is-then unwritten law will be conceived of as the law that goes without saying. It will be the law that has always been law: the law of nature, of nature's God, or of immemorial tradition. ${ }^{122}$

Read as written, however, the Constitution can allow no unwritten law of constitutional status on the basis of immemoriality. The Constitution de-natures law once and for all. The natural or immemorial as such has no status under the Constitution, through which an American people broke from the political surroundings in which it found itself and asserted the power to be the author of its own legal order. Only memorialization can generate constitutional law. Unwritten constitutional law under a written constitution is not, therefore, the law that goes without saying. It is only the law that comes, implicitly, with writing.

This is the lesson of Marbury: The judiciary may legitimately recognize an unwritten rule of constitutional law when that rule is a necessary condition of written constitutionalism itself.

And what are the conditions of written constitutionalism? There are three. It is a condition of the possibility of a people's being the author of its own

122. This was the understanding of unwritten law prevailing in pre-Revolutionary America and England. See J.G.A. POCOCK, THE ANCIENT CONSTITUTION AND THE FEUDAL LAW 33-55 (1957); GORDON S. WOOD, THE CREATION OF THE AMERICAN REPUBLIC 1776-1787, at 259-68 (1969). 
constitutional order: (1) that constitutional commitments be preserved over time (unless and until a new writing replaces them, which in turn must then be preserved); (2) that the people whose project of self-government the Constitution carries on be preserved over time; and (3) that the capacity of the people to re-write its constitutional order be preserved over time. Because these conditions-relating to threats against the people's past, present, and future authorship, respectively - are necessary to the very possibility of written constitutionalism, they may legitimately be regarded as part of our constitutional law whether or not the Constitution specifically enumerates them.

These unwritten conditions of written constitutionalism are in fact reflected in actual constitutional doctrine, sometimes explicitly recognized as an enforcement of unwritten rights, sometimes not so recognized. The first condition (as we have seen) is what justifies judicial review. The second justifies certain (but not all) aspects of the so-called dormant Commerce Clause doctrine and the right to travel. And it is with reference to the third condition that the right of privacy finds its legitimate place in constitutional law.'"' But a treatment of these issues will have to wait for another day.

\section{B. Interpretive Method}

Constitutional commitmentarianism demands a form of interpretation irreducible to any authoritative speech act-past, present, or future-by the maker of the commitment. This demand raises a problem. If interpretation of a constitutional commitment is not governed by a democratically authoritative will from any moment in the nation's history, how can it claim to be an interpretation of the commitment that the nation undertook? Where are judges supposed to look to give content to the commitments they must interpret, and what prevents judges from saying that a commitment means just anything at all?

In other words, how does commitmentarian interpretation work, and how can it differentiate between preserving a commitment, which is the proper judicial function, and founding or writing a new one, which no cour has authority to do?

\section{Paradigm Cases}

The answer lies in the use of paradigm cases.

Most of our constitutional guarantees were actuated by particular evils or abuses felt to be intolerable at the time of enactment: for example, slavery in the case of the Thirteenth Amendment, and the infamous "black codes" in the

123. See Jed Rubenfeld, The Righr of Privacy, 102 HaRv. L. Rev. 737. 805-07 (1989) 
case of the Fourteenth. ${ }^{124}$ Let's call such abuses the paradigm cases of a right's applicability. They are to be determined by historical inquiry; they are the core of what those who fought for the right were fighting to prohibit.

Paradigm cases form the spine of interpretation on the model of writing. The judiciary gives interpretive content to a constitutional provision by deriving principles and rules of application that capture the provision's paradigm cases. These principles and rules of application mediate between the generality of the text and the concrete cases that come to court. Their requirements are not known or specified all at once, but are elaborated on a case-by-case basis.

To "capture" the paradigm cases, a principle or rule of application must do more than merely include them in the prohibitions that it entails. The principle or rule must be such that the paradigm cases are at the very heart of what it prohibits. It should take its shape from an understanding of why the paradigm cases were so vicious that they merited a transformation in the nation's constitutional order. That understanding must in turn make sense of the history that gave rise to the constitutional commitment and the text that gives it expression. This return to the text is critical: A principle of application must capture the paradigm cases as cases of the proscription written into the text.

Take the Equal Protection Clause, and consider as a paradigm case Southern criminal statutes imposing the death penalty on blacks but not whites for certain offenses. Rules of application covering but not capturing such statutes would be: (1) all laws imposing the death penalty are unconstitutional; (2) statutes imposing death on blacks are unconstitutional unless they impose it equally on Asians, Hispanics, and all other racial minorities; (3) statutes discriminating against blacks are invalid if and only if enacted by a state below the Mason-Dixon line.

The first fails to make the paradigm case central to its prohibition. The second makes it central, but fails to make sense of the history that gave rise to the Equal Protection Clause. The third arguably makes the paradigm case central in a fashion cognizant of the constitutional history, but it does not survive the return to the text.

The centrality of the paradigm cases is what makes legislative history critical to constitutional interpretation. Courts should consult this history not to discern what some set of authoritative speakers would have said about the interpretive questions that judges alone must answer, but to illuminate the core ideas that underlie the constitutional language. Courts must consider what particular abuses most provoked those who framed and ratified the provision in question, and what it was about those abuses that most provoked them. For

124. See, e.g., The Slaughter-House Cases, 83 U.S. (16 Wall.) 36, 70, 81 (1872); BERGER, supra note 2, at 20-51; ERIC FONER, RECONSTRUCTION 257 (1989). 
this reason we are entitled to look with special regard to the writings of a Madison but also a Lincoln: not solely because Madison was so instrumental a Framer, but because both these men command deference as minds keen to the gravamen of the constitutional struggles of their time.

Is this intentionalism all over again, with a slightly wider scope? Not at all. Paradigm cases privilege one particular aspect of the original understanding: the abuses that those who fought for a constitutional right most centrally meant to abolish. Interpretation of constitutional guarantees on the model of writing takes its shape from what the Founders understood these guarantees centrally to forbid; it accords little or no deference to what they intended them to permit.

By "intent-to-permit," I refer to any understandings held by the framers or ratifiers of a constitutional provision as to what that provision allows government to do. To take the Fourteenth Amendment again, the understanding that government could continue to segregate schools and other facilities by race $^{125}$ was an example of intent-to-permit. So was the expectation that laws barring women from various positions ${ }^{126}$ would be left intact. These instances of intent-to-permit (initially honored by the Court ${ }^{127}$ but later repudiated ${ }^{128}$ ) deserve little or no deference in constitutional interpretation on the model of writing. If a court determines that the principle for which the paradigm cases stand also bars a law originally understood to be permitted under a constitutional right, then the court may with full authority (indeed must) so apply the right.

\section{Intent-To-Prohibit, Intent-To-Permit}

But what justifies this distinction between intent-to-prohibit and intent-topermit? Commitmentarianism.

As discussed above, those who initiate a foundational constitutional commitment are in one respect disabled from interpreting it properly. The full requirements of their commitment will become known only as the commitment proceeds from abstract principles into reality. But for similar reasons, we are disabled in another respect from interpreting the commitment properly. We have not lived under the former, overthrown legal order. Those who enacted our foundational constitutional commitments knew the core evils that demanded a constitutional transformation-what was worth fighting against, what particular oppressions were worth remaking the nation's legal order to

125. See, e.g., BERGER, supra note 2, at 117-33

126. See, e.g., Eleanor Flexner. Century of STRliggle 146-48 (1975). Ruth Bader Ginsburg. Sexual Equality Under the Fourteenth and Equal Rights Amendments. 1979 WASh. U L.Q. 161. 161-63 (1873).

127. See, e.g., Plessy v. Ferguson. 163 U.S. 537 (1896): Bradwell v. Illınoss. 83 U S (16 Wail.) 130

128. See, e.g., Brown v. Board of Educ., 347 U.S. 483 (1954); Stanton v Stanton, 421 U S 7 (1975) 
eliminate-in a way that later generations cannot. For this reason alone, the framers' judgment of what was to be prohibited by virtue of a constitutional right deserves deference.

More fundamentally, fidelity to paradigm cases is the means by which constitutional interpretation remains interpretation, rather than an exercise in rewriting. It is the constraint that preserves a commitment's core identity over time. So long as interpretation takes its shape from the paradigm cases, constitutional law will remain an interpretation of the commitments the people undertook, even though such law neither conforms nor purports to conform with popular will at any time in the nation's history or future.

And why not adhere to the framers' judgments altogether? Wouldn't that preserve the recognizability of the nation's original commitments still better? Yes, but only at the price of dishonoring them. Commitmentarianism is compatible with according privileged status to the original understanding of a right's core prohibitions, but not with according such status to the original understanding in its entirety. The latter would reduce commitmentarian interpretation to consensualism. It would make the mistake both of equating self-government with the implementation of a single moment's democratically authoritative will and of failing to see that those who launch a constitutional commitment, having never lived under the institutions and principles they have framed, are in no position to specify all the requirements that their commitments will entail.

To be sure, distinguishing between intent-to-prohibit and intent-to-permit in this way introduces an interpretive asymmetry favoring expansion. There is a floor, but no ceiling. The core prohibitions must be honored, but later courts are free (indeed required) to consider whether a right also entails additional prohibitions apart from or contrary to the original understanding. Indeed there is even a kind of internal pressure toward expansion. The judiciary's task is to generalize: to formulate and apply general principles or rules of application capturing the paradigm cases. Add to this the ratchetlike effect of judicial expansions of constitutional rights (it is far easier for a court to increase the scope of a guarantee than to cut back on constitutional rights already established), and what is produced is a recipe for the gradual but everincreasing expansion of constitutional rights beyond their original purview.

To some, this conclusion will appear an insuperable objection to commitmentarian interpretation, or at least a consequence to bemoan. But such an expansion of rights is a fact of our constitutional history, and it is a mark of honor. It is the sign of an effort to live up to principles of freedom and justice at the cost of unsettling ingrained ways of life.

No one should profess surprise when a principle of justice or freedom he espouses proves to entail, upon a genuine commitment to it, requirements beyond what he originally foresaw. Moral astigmatism is general in man; inflamed by the injustices perpetrated against him, or infuriated by those next 
door, he can never quite make out those occurring in his own home, under his own name. Chief Justice Taney once declared, explaining why a black man could not be deemed a citizen or indeed a man for constitutional purposes, that the distinguished "men who framed" our founding documents were "high in their sense of honor, and incapable of asserting principles inconsistent with those on which they were acting." 129 On the contrary; but inconsistency is a small price to pay for greatness. If our constitutional rights have gradually but continually expanded, this expansion proves only that we have struggled to take our commitments seriously. What the framers fought to prohibit must remain the foundation of our constitutional rights, but it is up to the future to determine what else these commitments require.

\section{Powers}

I have been referring so far to constitutional rights. As to constitutional grants of power, interpretation on the model of writing proceeds in exactly the same fashion, only with the polarity reversed. Here, the paradigm cases of a provision's applicability will be instances of intent-to-permit, and these cases form the spine of interpretation. Courts would formulate principles or rules of application to capture these cases, creating the same internal pressure toward expansion, while instances of the intent-to-prohibit would receive little or no weight.

Reading the Constitution as written thus renders intelligible an extraordinary feature of today's constitutional doctrine: the coexistence in our constitutional law of an aggressive individualism and an equally aggressive statism - the parallel expansion of rights and powers. Perhaps this phenomenon reflects not a contradiction, but the elaboration of a single interpretive method. Perhaps it reflects an effort to capture and to elaborate what those who fought for our Constitution centrally fought to accomplish-prohibitions in the case of rights, permissions in the case of powers.

It may be questioned, however, whether the interpretive method described so far can account for what the Supreme Court has done with Congress' powers. In particular, someone might doubt whether any principle consistent with text and history can account for modern Commerce Clause cases. Take

129. Scott v. Sandford, 60 U.S. 393, 410 (1857) (Taney, C.J.) (emphasis added) Compare Painck Henry's self-description:

Would any one believe that I am master of slaves of my own purchase? I am drawn along by the general inconvenience of living without them. I will not. 1 cannot, justufy $i t$, however culpable my conduct, I ... own the excellence and recutude of (vinue's) precepts. and ... lament my want of conformity to them. . . I could say many things on this subject, a serious view of which gives a gloomy prospect to future umes.

6 GEORGE BANCROFT, HISTORY OF THE UNITED STATES. FROM THE DISCOVERY OF THE AMERICAN Continent 416-17 (14th ed., Boston, Little. Brown \& Co. 1866). 
Wickard v. Fillburn, ${ }^{130}$ in which the Court famously held that the power to regulate commerce among the states extended to a regulation imposing a limit on the amount of wheat grown by an individual farmer for consumption on his own farm. The truth (someone might say) is that Wickard was a judicial surrender, a re-writing of the text, caused by the enormous political pressures that arose in the wake of the Great Depression. ${ }^{131}$

Political pressures doubtless contributed to the result in Wickard, but this observation does not answer the question of whether the decision is an instance of legitimate commitmentarian interpretation: whether, in other words, the Court identified a principle of application for the Commerce Clause traceable to the paradigm cases and plausibly applied that principle to the facts at hand. In fact the Court did both.

Here is Justice Jackson's well-known formulation of the reach of the commerce power in Wickard: "[E]ven if appellee's activity be local and though it may not be regarded as commerce, it may still, whatever its nature, be reached by Congress if it exerts a substantial economic effect on interstate commerce . . . ."132 The Court held further: "That appellee's own contribution to the demand for wheat may be trivial by itself is not enough to remove him from the scope of federal regulation where, as here, his contribution, taken together with that of many others similarly situated, is far from trivial." 133

However contrary to original intent the decision in Wickard may have been, the principle on which it is based is nonetheless traceable to a very early understanding of the particular measures that the Commerce Clause permitted the federal government to take. This is not the place for a complete study of Commerce Clause paradigm cases, but one such case appears to have been Congress' authority over the country's interstate navigable waters-in particular, its authority to prohibit the creation of obstructions, such as a low bridge or dam, on such waters. ${ }^{134}$ The building of a single bridge or dam

130. 317 U.S. 111 (1942).

131. See, e.g., BORK, supra note 1, at 56-57. Bruce Ackerman argues a similar position, claiming that the Court's post-New Deal validation of an "activist national government" has to be understood as a species of constitutional amendment. ACKERMAN, supra note 15, at 47-50, 103-04, 107.

132. 317 U.S. at 125 .

133. Id. at $127-28$.

134. See United States v. Coombs, 37 U.S. (12 Pet.) 72, 78 (1838) (Story, J.) (holding that commerce power "extends to such acts ... which interfere with [or] obstruct ... commerce and navigation ... among the states. . . Congress have, in a great variety of cases, acted upon this interpretation . . . from the earliest period after the constitution .... .); see also Willson v. Black Bird Creek Marsh Co., 27 U.S. (2 Pet.) 245, 251-52 (1829) (Marshall, C.J.); Gibbons v. Ogden, 22 U.S. (9 Wheat.) 1, 197 (1824) (Marshall, C.J.). Regulation of navigable waters was the subject of Madison's resolutions for the Annapolis Convention and of the 1785 compact between Maryland and Virginia, both of which were important precursors of the commerce power written into the Constitution. See, e.g., 2 JOHN RANDOLPH TUCKER, THE CONSTITUTION OF THE UNITEd STATES 520-21 (Henry St. George Tucker ed., Chicago, Callaghan \& Co. 1899). Even those who denied that the Commerce Clause authorized federal construction of roads, canals, and so on, agreed that Congress "may, under this power, declare that no bridge shall be built which shall be an obstruction to the use of a navigable water." E. PARAMALEE PRENTICE \& JOHN G. EOAN, THE 
may itself take place entirely within a state; it may not constitute commerce; and it may impose only a negligible burden on interstate commerce. Because, however, the Commerce Clause committed to the federal government the power to reach such a case, a plausible principle of application for that Clause is the aggregate-effect-on-commerce test stated in Wickard. ${ }^{135}$

A harder case is presented by those modern laws through which Congress has made use of its broadened Commerce Clause jurisdiction to achieve principally noncommercial ends. ${ }^{36}$ Even here, however, a supporting paradigm case may exist: Congress' power under the Commerce Clause to prohibit the foreign slave trade, which it exercised as of January $1,1808,{ }^{137}$ the very day it became constitutional to do so. ${ }^{138}$ Those who fought for a Congress endowed with this power did not pretend that the permissible grounds for abolishing the slave trade were only commercial in nature. ${ }^{139}$

One might, however, grant all this but still question in what sense an interpretive process can claim to be honoring the Constitution's commitments if it is willing not merely to depart from original intent, but to depart from it so fundamentally that, had the Framers or ratifiers known what was to be made of their language, the Constitution might well never have been enacted. Consider not the slave trade, but slavery itself. Assume that the Southern states would never have ratified the Constitution had they understood that Congress was to have power to regulate slavery within state lines, and assume that the

COMmerce Clause of the Federal Constitution 109 (Chucago. Callaghan \& Co 1898) (quoung Pennsylvania v. Wheeling \& Belmont Bridge Co., 59 U.S. (18 How.) 421.442 (1856) (McLcan, J.. dissenting)).

135. For just these reasons, an "effect-on-commerec" test was evident in Commerce Clause case law long before Wickard. See, e.g., Houston. E. \& W. Tex. Ry. v. Unted States. 23.4 U.S. 342, 354 (1914); Gibbons v. Ogden, 22 U.S. at 194-95.

136. See, e.g., Katzenbach v. McClung. 379 U.S. 294 (196-4) (upholding antidiscrmmnation statute as exercise of Commerce Clause power).

137. See Act of Mar. 2, 1807, ch. 22. 2 Stat. 426.

138. Prior to 1808 , no such prohibition could be enacted. See U.S. CoNst art. 1. $\$ 9$. cl 1 That Congress would have the power to ban the foreign slave trade (after 1808) under the Commeree Clause was well understood. See, e.g., THE FEDERALIST No. 42, at 264 (James Madison) (Clinton Rossiter ed.. 1961) (referring to proposed power "to regulate foreign commerce, including a power to prohibit. after the year 1808, the importation of slaves"); Paul Finkelman. Slaven and the Constisutional Conventson: Making a Covenant with Death, in BEYOND CONFEDERATION: ORIGINS OF THE CONSTITUTION AND AMERICAN NATIONAL IDENTITY 188, 209-23 (Richard Beeman el al. eds., 1987).

139. See, e.g.. THE Federalist No. 42, al 266 (James Madison) (Clinton Rossiter ed.. 1961) ("It ought to be considered as a great point gained in favor of humanity that a penod of tuenty years may terminate forever, within these States, a traffic which has so long and so loudly upbraded the barbansm of modem policy ... ."); see also THE FEDERALIST No. 54. at 337 (James Madison) (Clinton Rossiter ed. 1961) ("[T]he slave is no less evidently regarded by the law as a member of the sociely, not as a part of the irrational creation; as a moral person, not as a mere article of property.").

To be sure, it is far from certain that a paradigm case of Congress" power to regulate commerce "with foreign Nations" should be treated as a paradigm case of Congress" power to regulale commerce "among the States." U.S. CONST. art. I, $\$ 8, \mathrm{cl}$. 3. Whether Congress had the power as of 1808 to abolish the interstate traffic in slaves was never settled. See Walter Berns. The Constiturion and the M/tgration of Slaves, 78 YALE L.J. 198, $198-99$ (1968). Nonetheless, the words "to regulate Commerce" appear only once, preceding both prepositional phrases, and it is at least possible to take the vew that Congress" power to regulate commerce as such, whether foreign. intersiste. or Indian. etther includes or does not include the power to regulate it for moral or general-welfare purposes. 
supporters of the Constitution, Northern and Southern, assured everyone that the new federal government could do no such thing. In interpreting Congress' powers, why shouldn't this core understanding be treated as a paradigm case of inapplicability, receiving the same definitive status as is accorded to instances of intent-to-permit? Shouldn't a truly commitmentarian court reject a proffered principle of application for any of Congress' powers that violates this core expectation? Yet the Wickard formulation would surely have placed slavery itself within the reach of Congress' commerce power.

This is a deeper objection and requires a more complex answer. Interpretation on the model of writing could proceed in the fashion the objector describes. Indeed, in the case of the Commerce Clause, slavery probably figured as just such a paradigm case of inapplicability for almost a century. ${ }^{140}$ But if the question is whether interpretation on the model of writing must proceed in this fashion, the answer is no. And the reason is that no writing-no substantive textual proposition-commits the power to regulate slavery to the states.

I do not mean that no provision expressly or specifically so states. Constitutional meaning need not be so plain. Had the Constitution contained any substantive proposition, no matter how general, such as "Congress shall pass no law in exercise of the police power," or even, "the states alone shall have power to regulate matters of local concern," then interpretation on the model of writing would have been not only stuck with the paradigm cases instantiating this power (or limitation), but obliged to expand on them in the manner described above.

The Constitution, however, contains no such provision. The scope of exclusive state power is marked out entirely by negative implication. Even the Tenth Amendment refers only to the "powers not delegated to the United States." ${ }^{141}$ As a result, there is no substantive proscription or prescription for the supposed paradigm cases of exclusive state power to be paradigm cases of. Without such a writing, the original understanding that Congress had no authority to abolish slavery no more commands absolute deference than does the original understanding of the Fourteenth Amendment, according to which it permitted the denial of the equal protection of the laws to an entire sex.

That the Southern states' consent to the Constitution may have rested on this point does not alter the conclusion. Commitmentarianism is not intentionalism, and it is not consensualism. We are just as capable of underestimating the requirements of our institutional or relational commitments as we are our commitments to principles. A man may commit himself to a marriage on the understanding that his professional autonomy will in no way

140. See, e.g., The Passenger Cases, 48 U.S. (7 How.) 283 (1849); Mayor of New York v. Miln, 36 U.S. (11 Pet.) 102 (1837).

141. U.S. CONST. amend. X. 
decrease. So too he may commit his commercial affairs into another's hands, believing that his marital life, his freedom of speech, or even his thoughts will remain exclusively his own. Only time will tell.

Early after enactment of a constitutional provision, when the bonds of consensualism are the strongest available, a court interpreting that provision must overreach original intent only with utmost care. Not simply because the executive may be unwilling or unable to enforce the court's holdings, but because insufficient time will have elapsed to have made clear what else, beyond the original understanding, the constitutional commitment might entail. In 1789, had Congress asserted that slavery was destroying the nation's interstate commerce, the claim would not only have been received as a betrayal of the Southern states' acceptance of the Constitution; it would have seemed (and would probably have been) a mere pretext for the promotion of regional or moral interests. But by 1942, the Court could accept another legislative judgment as plausible even though it would have seemed equally extravagant 150 years earlier: that the economic decisions of individual farmers, if left to the pursuit of their own interests, might conduce to nationwide economic catastrophe.

I am not suggesting that the Great Depression somehow rendered selfevident the proposition that Congress' commerce power had to reach as far as the Court has now held. A valid commitmentarian interpretation of the Commerce Clause today could easily stop short of Wickard (or, accepting Wickard, could limit that case in a variety of ways). All that follows from the foregoing is that the Wickard rules of application for the commerce power reflect a legitimate judicial effort to interpret the Constitution as written, in light of the nation's history and its economic development. Reading the Constitution as written makes modern Commerce Clause doctrine not necessary, but possible-not inexorable, but intelligible.

\section{Precedent}

The final and in some respects most important element of interpretation on the model of writing is precedent.

Most constitutional interpretation today takes the form of an interpretation of past decisions. This layering of interpretation upon interpretation is a thorn in the side of the model of speech, which can hardly comprehend the mixture of exegesis and policymaking that makes up the reading of precedent. ${ }^{1+2}$ From the perspective of the model of speech, it's as if a series of historical accidents had conspired to interpolate the English common-law method, with its latitudinous but covert tradition of judicial discretion, into the hear of

142. See, e.g., BERGER, supra note 2, at 297 (refering to constitutional precedent as "judicial incrustations"). 
American self-government, where judicial discretion ought to have been minimized.

But the common-law method of building on precedent is in every respect a model of writing-modeled interpretation. To begin with, there is no precedent in our system without a citable text; interpretation of precedent always begins with a text. Moreover, the precedent is polygraphic, not only because virtually every opinion of controlling authority in the American legal system must have been joined by at least two judges, but because the characteristic task of following precedent involves the interpretation and reconciliation of lines of cases.

For these reasons, the prevailing methodology of interpreting precedent has never been intentionalist. Generally speaking, American adjudicative practice formulates the task of interpreting precedent as one of identifying and construing the principles or rules of application for which the prior decisions stand. Some decisions-for reasons of age but not only of age-become paradigm cases of precisely the sort described above. Capturing these cases, or applying a rule previously announced, will also typically involve a return to the text, to see whether a proposed decision or proposition is supported by the language used in the relevant prior opinions.

Thus we should view the primacy of case law in constitutional law neither as a compromise with self-government nor as a strange historical corruption by which American constitutional interpretation turned into English common law writ large. On the contrary, the case-law development of constitutional law is the interpretation of the Constitution as written: a process of elaborating constitutional principles of application on the basis of paradigm cases; of establishing new paradigm cases (although inferior in status to the original ones); and of working out the requirements of principled commitments as they unfold in practice. In other words, it is a textual process entirely distinct from any hypothetical dialogue in which some authoritative figures somewhere else are enabled to speak their minds.

But the feature of this process most crucial to written constitutionalism is not its writing-modeled methodology. It is the element of temporal extension. Some constitutional principles must be adhered to over time if there is to be any constitutional self-government at all. This means that part of reading the Constitution rightly - of reading it as a writing-is that interpretations be adhered to over time.

This interpretive demand produces the peculiar ambivalence of age in the doctrine of stare decisis. The longer a principle has been adhered to in practice-the more it has been tested by a variety of circumstances, the more it has worked its way into the life of the nation-the more deference it is due, because (as discussed earlier) longevity in constitutional principle is evidence of soundness, and because any inter-generational adherence to a principle, once won, should not be lightly sacrificed. But a decision from long ago that has 
been of no great significance in shaping constitutional doctrine-a decision whose principle has not inscribed itself into social practices in material respects-is merely dated, rather than temporally extended, and therefore carries far less weight.

Even with respect to a precedent that has worked its way into the life of the nation, however, this view of stare decisis demands re-examination after a lapse of time sufficient to see how the principle has fared in practice. Constitutional principles of application must have a chance to succeed, in order that the Constitution itself may have a chance to succeed; that is the function of stare decisis. (It is for this reason that overturning a very recent decision gives rise both to the feeling that a disservice has been done to the project of constitutional interpretation and to the sense that not too much damage has occurred.) But for the very same reason, there will come a time when a legal rule or principle has had its chance, and its measure must then be taken. In this respect, longevity, even where a principle has been tested and applied to various circumstances, can weaken as well as strengthen. For the consonance of a principle of application with the constitutional commitment that it interprets can be finally measured only in practice and over time.

\section{Application: The Just Compensation Clause}

The interpretive method outlined here may best demonstrate its usefulness by accounting for those deeply established doctrines touched on already-such as the unconstitutionality of sex discrimination and racial segregation under the Equal Protection Clause, or the enormous expansion of the federal Commerce Clause power-that intentionalism and processualism cannot satisfactorily explain at all. On the other hand, it is also important to draw examples from less well-established doctrine, to show in what way reading the Constitution as written would shed light on problems that remain at present a constitutional morass. I explore one such example here.

Consider the Just Compensation Clause of the Fifth Amendment, the case law of which has more than once been described as "chaos."1+3 Entire books seem to be written every year about the Compensation Clause, and my views on the subject appear in a separate essay. ${ }^{14}$ I want simply to demonstrate how the interpretive method outlined above furnishes a distinct approach to the problem, eliminating some proposed interpretations of the Clause and pointing instead to another.

We begin with the spare text: "nor shall private property be taken for public use without just compensation."145

143. E.g., Bruce A. ACKerman, Private Property and the Constmumon 8 (1977): Jeremy Paul. The Hidden Structure of Takings Law, 64 S. CAL. L. REV. 1393. 1524 (1991).

144. Jed Rubenfeld, Usings, 102 YALE L.J. 1077 (1993).

145. U.S. CONST. amend. V. 
Current doctrine establishes a two-tiered rule of application for this proscription. First, governmental actors may take private property only for a legitimate state purpose; otherwise the taking is unconstitutional per se, with or without compensation. ${ }^{146}$ This rule is supposed to follow from the phrase "for public use," now referred to as a separate clause of its own, the "Public Use Clause."147 Second, if governmental actors "take" property for a legitimate state purpose, then they must compensate its owner. ${ }^{148}$ The definition of a "taking" is what has so bedeviled the Court and commentators.

Does this rule of application, even at this level of generality, survive the return to the text? Perhaps, but if so, only with strain. I am not the first to observe that the text does not read, "Private property shall not be taken except for a public purpose, nor without just compensation."149 A strange grammar operates in the current construction of the Compensation Clause, without which "for public use" could not be read as a separate requirement of its own, divorced from the question of what makes a governmental taking of property compensable. Without this strange grammar, "for public use" could figure rather as an integral piece of the Clause as a whole, prescribing the decisive element of a compensable taking.

In other words, perhaps courts should be asking not only what constitutes a "taking" of property, but what constitutes a "using." The well-known case of Miller $v$. Schoene held that the government did not "take" property when it felled a grove of cedar trees to prevent the spread of cedar rust (a harmless condition for cedars) to a nearby apple orchard. ${ }^{150}$ Miller has occasioned a great deal of perplexity and criticism, especially over the harm-prevention exception to the compensation requirement that it appears to endorse. ${ }^{151}$ And Miller is bound to be perplexing, so long as the only question posed is whether the state took someone's property. The state-ordered felling of someone's trees is undoubtedly a deprivation of property. But if the decisive question were whether the state took property and put it to use, the matter would appear in a different light.

The text, however, is only suggestive of this result. The real interpretive work begins when we turn to the core offenses that the Compensation Clause was enacted to prohibit. The historical records, sparse though they are, indicate two paradigm cases. The first was of course the exercise of the eminent domain power, such as the appropriation of a piece of land in order to lay a road or to build a mill. Payment for acts of eminent domain was not always

146. See, e.g., Hawaii Hous. Auth. v. Midkiff, 467 U.S. 229, 239-40 (1984).

147. E.g., id.

148. See, e.g., id.

149. See, e.g., JoHN LewIS, A TREATISE ON THE LAW OF EMINENT DOMAIN IN THE UNITED STATES at ii (Chicago, Callaghan \& Co. 1888); William B. Stoebuck, A General Theory of Eminent Domain, 47 WASH. L. REV. 553, 591 (1972).

150. See Miller v. Schoene, 276 U.S. 272 (1928).

151. See, e.g., TRIBE, supra note 4 , at 577 . 
forthcoming in colonial America, and the Just Compensation Clause has from the outset been understood to make such payment mandatory. ${ }^{152}$ The second core case, often forgotten in modern discussions, was the uncompensated impressment of personal property by an army. ${ }^{153}$

What rule of application, what principle, captures these fact patterns? More than one. Capturing the paradigm cases in a rule or principle is a normative task, for which no algorithm will ever be found, and it is unlikely that the paradigm cases underlying any constitutional provision will dictate a single norm to the exclusion of all others. But if the paradigm cases do not rule in any particular norm, they do rule out some approaches to the Just Compensation Clause that have recently received substantial attention.

For example, consider the idea that courts ought to resolve "takings" law by economic inquiry ${ }^{154}$ and award compensation only when it is economically efficient to do so. Although early efforts in this area pointed to a broad compensation requirement (on the theory that requiring compensation would make governmental decisions more efficient and that it would prevent underinvestment by property owners), ${ }^{155}$ the recent and more sophisticated work indicates that a quite narrow compensation rule would follow (because of the problem of overinvestment and because of social-choice problems in governmental decisions to compensate). ${ }^{156}$ For example, if government appropriated land to build a road or power plant, compensation might well not be due to the owner for the loss of his improvements, such as his house. ${ }^{157}$

Now if the Compensation Clause means anything, it means that one whose house is taken by exercise of eminent domain is guaranteed just compensation for the loss. Of course the Clause can be read otherwise. But paradigm cases are constitutive of meaning, not cases to which application is made after a process of interpreting meaning. If a reading of a constitutional clause can

152. Rubenfeld, supra note 144 , at 1081 .

153. As John Jay wrote: "I . . take the Liberty of calling the Altention of my Countrymen to a Subject, which however important seems to have passed without due Notice, 1 mean the Practuce of impressing Horses, Teems, and Carriages by the mulary. . Wthout any Authorty from the Law of the Land." John Jay, A Hint to the Legislature of the State of New York (1778), in 5 The FotvDers" CONSTtTUTION 312 (Philip B. Kurland \& Ralph Lemer eds.. 1987). Jay added that this practuce uas contrary to "Law and Justice," which required that "Damages" be paid when individuals are subjected to such "oppression." Id. at 313.

154. See, e.g., Lawrence Blume et al., The Taking of Land: When Should Compensatwon Be'Patd". 99 Q.J. ECON. 71 (1984); William A. Fischel, Introduction: Utultartan Balancing and Formalism in Takengs. 88 COLUM. L. REV. 1581 (1988); Louis Kaplow, An Economic Analysis of Legal Transituons, 99 HARV L. REV. 509 (1986).

155. See, e.g., ACKERMAN, supra note 143, at 44: Lawrence Berger. A Polics Artalisis of the Taking Problem, 49 N.Y.U. L. REV. 165, 195-207 (1974).

156. See, e.g., Daniel A. Farber, Public Choice and Jusi Compensarton, 9 CovST COvivituTakY 279. 291-94 (1992); William A. Fischel \& Perry Shapiro. Takengs, Insurance, and bichelman: Comments on Economic Interpretations of "Just Compensation" Law. 17 J. LEGAL STUD. 269. 269-77 (1988). Kaplow, supra note 154 , at $602-03$.

157. See, e.g., Blume et al., supra note 154, at 71, 90: Fischel \& Shapiro, supra nole 156, at 271-7.4. Susan Rose-Ackerman, Against Ad Hocery: A Comment on Mtchelman. 88 Col.L.M L. REV 1697. 1702-03 (1988). 
reverse the holdings most central to its history-most constitutive of the commitment itself - then there is no longer a meaning to be preserved. The commitment can only be dishonored or re-written; it cannot be interpreted.

Another rule of application ruled out in this way is the one suggested by Professor Michelman in a very influential article twenty-five years ago. ${ }^{\text {Is }}$ Michelman argued that compensation ought to be paid when the state is engaged in nonprogressive wealth redistribution. Redistribution from wealthy to poor is ethically warranted, but laws shutting down (say) a foundry for the benefit of neighboring homeowners demanded compensation: "[N]o widely shared ethical precept ... warrant[s] a redistribution from a member of the class of foundry owners to members of the class of residence owners."139

This approach, too, fails to sustain the paradigm cases, because paradigmatic exercises of eminent domain characteristically redistributed wealth from a class of better-off persons (real property owners) to a class of less well-off persons (some large section of the public). A Just Compensation Clause converted into a vehicle for implementing a broad-brush, ahistorical ethical standard would belong to the same family as a Just Compensation Clause converted into a vehicle for a broad-brush, ahistorical efficiency standard.

Another rule of application sometimes advocated for the "Takings" Clause derives from an extreme, libertarian anti-redistributive principle. On this view, in most cases when the state redistributes wealth from a minority of the populace to a majority, either the redistribution is unconstitutional per se, or else compensation is due. ${ }^{160}$ This principle, it might be said, does capture the paradigm cases.

Perhaps so, and perhaps it survives the return to the text, even though it accepts the same strained reading of the "Public Use Clause" that current doctrine establishes. Let's suppose that it passes both these tests. What then? If the extreme libertarian principle were the only one compatible with the paradigm cases, then the Constitution would be stuck with it. But this is certainly not true.

When we examine the paradigm cases, at least one other principle comes into view: the "usings" principle suggested above. Under this rule, when the state merely diminishes the value of certain property, denies to owners certain property rights, or redistributes wealth, it owes no compensation. But when the state not only takes property, but also, whether through regulation or by direct impressment, effectively forces a piece of property into state-dictated service, it must pay. Thus if government bans the drinking of alcohol, no compensation

158. Frank I. Michelman, Property, Utility, and Fairness: Comments on the Ethical Foundations of "Just Compensation" Law, 80 HARV. L. REv. 1165 (1967).

159. Id. at 1183 . (1985).

160. See Richard A. Epstein, Takings: Private Property AND the Power of EMINent Domain 
is due despite the massive losses thereby imposed on some property owners; the government does not affirmatively put any property to use. ${ }^{161}$ If, however, government does not merely shut down a factory but seizes it and puts it or its inventory to use, then compensation must be paid. ${ }^{162}$

The paradigm cases both suggest this rule. Eminent domain has historically been distinguished from other forms of governmental action that deprive persons of property values precisely by the fact that in eminent domain the government puts the property taken to a specific. publicly mandated use. ${ }^{163}$ Conscripting property in wartime is another vivid instance of the affirmative impressment of property into state-dictated use. The usings principle, moreover, captures both these cases as cases of the specific proscription expressed in the text.

Now suppose (counterfactually) that both the usings rule and the libertarian takings rule equally captured the original paradigm cases and the constitutional text. How is a court to choose between them?

The first source of resolution would be precedent. Which of these principles better captures the landmark cases and the great run of subsidiary decisions? Of course landmark cases may always be wrong, and they ought never to serve as apologies for a reading that both spurns what the Founders fought for and cannot survive a return to the text. But where history and text do not decide between two proposed readings, precedent becomes a paramount source of disposition, for all the reasons discussed above. Constitutional commitments are not born fully formed. Whether we like it or not, the judiciary's weaving of our commitments into the life of the country is part of constitution making itself.

Another source of resolution is the extent to which application of either rule would have the judiciary ordering a fundamental overhaul of major social institutions. This was the difficulty faced by the judges who decided Brown $v$. Board of Education. A court should launch the nation on a project of this magnitude only for the most urgent, the most irresistible, constitutional reasons.

Ultimately, however, the choice between two possible constitutional principles is a normative matter, to be decided on normative grounds. Judges must in the end be prepared to defend the principles they read into the text as

161. The landmark case upholding an uncompensated prohibition lau is Mugler 、 Kansas. 123 U S 623 (1887). Current doctrine has considerable difficulty explaning why laws that make formerly legal and valuable property into contraband do not require compensation. See Rubenfeld, supra note 1+4. at IIS1-52.

162. Compare United States v. Central Eureka Mıning Co.. 357 U.S. 155 (1958) (mine shut: no compensation due) with United States v. Pewee Coal Co.. 341 U.S. 114 (1951) (mine taken over by government officials; compensation due).

163. See, e.g., LEWIS, supra note 149. $\$ 6$ (distinguishing emunent doman from "police power" on this ground); CARMAN F. RANDOLPH, THE LAW OF EMINENT DOMAIN IN TIE UNITED STATES 23 (Boston. Little, Brown \& Co. 1894) ("[T] axation exacts the money which is supposed to represent the contributor"s share of the public expense, while the eminent domain exacts spectific property for specific uses ") 
constitutional principles: as principles deserving a place in the nation's charter, meriting what they cost.

For a fuller treatment of the precedential and normative aspects of the libertarian and usings rules, the reader will have to look elsewhere. Very briefly, as to precedent, a usings principle would explain the landmark cases, conform with the great run of decisions, and resolve long-gnarled distinctions. ${ }^{164}$ The same cannot be said of the libertarian rule; on the contrary, its proponents seem to delight in the extent to which it overthrows precedent and dictates the dismantling of the regulatory state. ${ }^{165}$

On the more fundamental issues: A judge who entertains the idea of constitutionalizing an anti-redistributive principle through the Compensation Clause must at some point ask whether that principle assumes the full justifiability of the current distribution of wealth, and whether that assumption is tenable. As for the usings rule, it draws not on natural-rights thinking (as does libertarianism), nor even on basic notions of fairness, but on an antiinstrumentalization or anti-totalitarian principle fully consonant with the project of written constitutionalism.

The libertarian's natural right to define oneself as one wishes or to do as one likes with one's own property (absent force or fraud) has never been a part of American constitutional law. But a right not to have one's life or one's things taken over and affirmatively put to use by the state is a guarantee necessarily part of a people's effort to be the author of its political order. If the state had unrestrained power to dictate the use of private property, it could substantially write the scripts of its citizens' lives. ${ }^{166}$ The relation of authorship central to democracy on the model of writing could then be reversed. Individuals could be made the mere means, and the state the end, of government.

This last step shifts ground from method to substance. A people's authorship of its own legal order over time is not compatible with totalitarianism-even with a totalitarianism endorsed by a majority of living citizens at a given historical moment. Hence a substantive principle against state instrumentalization of its citizens is built into the very project of written constitutionalism. And this principle has an interpretive role to play after method has run its course.

\section{CONCLUSION}

Here is a paradox. The more insulated from popular will a constitution is, the less democratically legitimate it seems. But the more legitimate it is

164. See Rubenfeld, supra note 144 , at 1124-30.

165. See, e.g., EPSTEIN, supra note 160, at 324, 327-28.

166. For a much fuller discussion of these points, see Rubenfeld, supra note 144, at 1139-48. 
made-for example, by facilitating the amendment procedures or by allowing the legislature to overrule judicial interpretations-the less it functions as a constitution.

Speech-modeled thought can never escape this paradox. Constitutional democracy is incomprehensible from this perspective; it is an oxymoron. And so it will always seem to us, until we see in self-government something more than governance by the voice of the people, no matter how authentic that voice, no matter how deliberate.

This is not to denigrate the vigorous public debate of constitutional values. On the contrary, there must be a decision to initiate any written political commitment. In rendering this decision, the old constellation of public debate, popular assembly, and the enactment of law by vote of this assembly may be irreplaceable. Speaking is a necessary precursor of writing. But once the commitment to writing has begun, self-government and interpretation leave speech behind and enter the time-spanning domain of the written. 


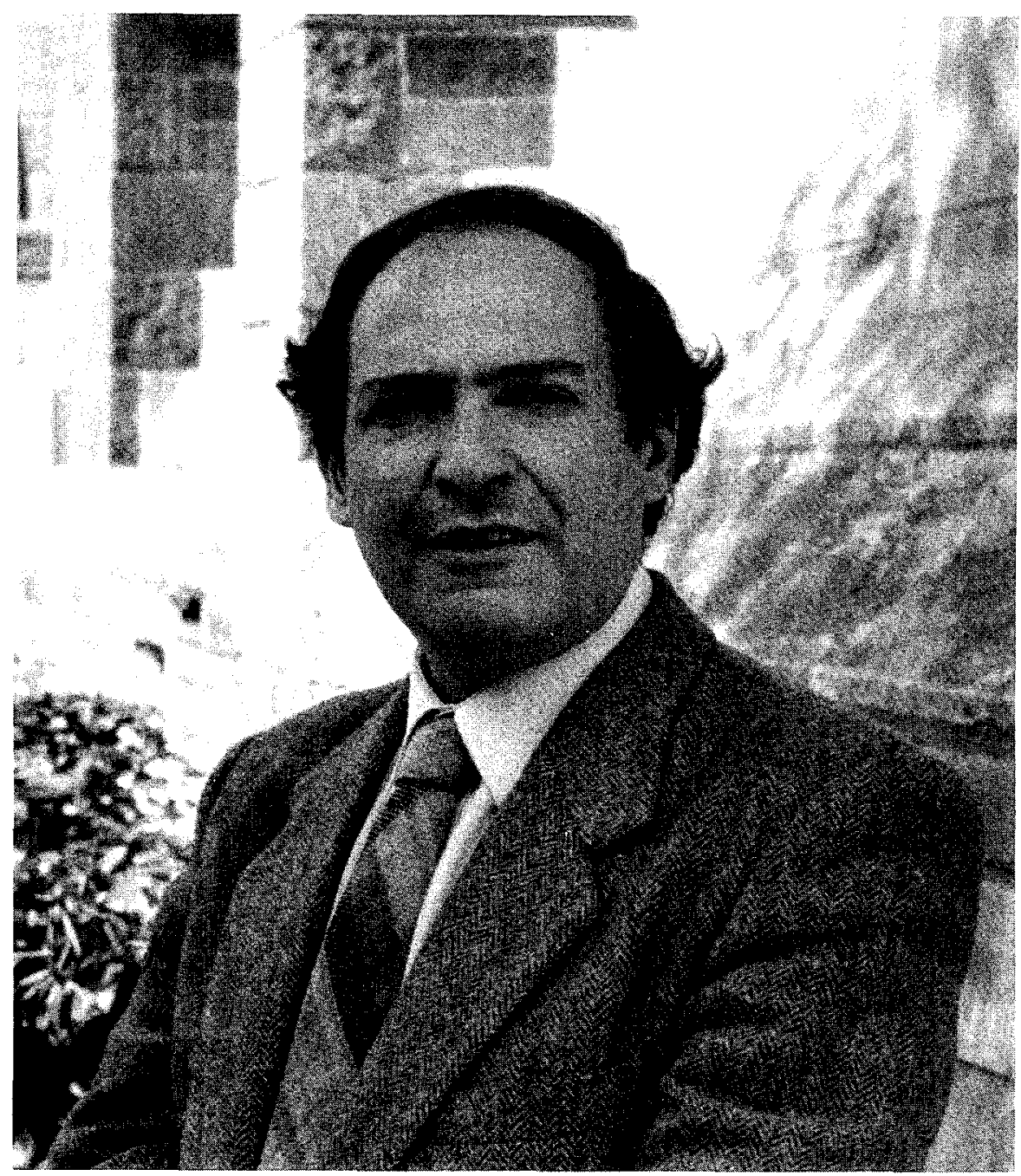

Photo by Catherine Iino.

Carlos Santiago Nino

November 3, 1943-August 29, 1993 